\title{
Anxiogenic-Like Effects Limit Rewarding Effects of Cocaine in BALB/cByJ Mice
}

\author{
Vincent David, Ph.D., Lisa H. Gold, Ph.D., George F. Koob, Ph.D., and Pierre Cazala, Ph.D.
}

Previous studies have reported intravenous cocaine selfadministration behavior in several strains of mice with the exception of $B A L B / C B y J$, a strain considered a mouse model of high emotional reactivity. The present experiments further investigated acquisition of self-administration in $B A L B / c B y J$ mice using a low dose and a habituation session. Following evidence of an initial drug-seeking behavior, we observed a progressive decline of intravenous self-administration. Pretreatment with diazepam $(0.5 \mathrm{mg} /$ $\mathrm{kg}, \mathrm{IP})$, reinstated cocaine-maintained responding. To test the hypothesis that injections directly into a rewardrelevant brain region might support consistent cocaineseeking behavior, BALB/cByJ mice implanted in the nucleus accumbens (NAc) or the caudate-putamen nucleus (CPu) were trained to discriminate between the arm enabling a microinjection of cocaine (30 pmol/50 $\mathrm{nl}$ or $150 \mathrm{pmol} / 50 \mathrm{nl}$ ) and the neutral arm of a Y-maze. Only NAc subjects exhibited a spatial discrimination toward the cocainereinforced arm and the D2 antagonist, sulpiride $(50 \mathrm{mg} / \mathrm{kg}$, IP) eliminated intra-NAc cocaine self-administration. However, after several days of cocaine self-injection, animals developed an approach/avoidance-like behavior between the start box and the reinforced arm. This behavior was suppressed by systemic diazepam (1 $\mathrm{mg} / \mathrm{kg}$, IP) pretreatment. We conclude that: (1) medio-ventral NAc is involved both in the rewarding (via a D2 dopaminergic mechanism) and aversive effects of cocaine in mice; and (2) anxiolytic pretreatment (diazepam) indirectly enhanced the reinforcing properties of cocaine in $B A L B / C B y J$, suggesting that emotionality can act as a protective mechanism against stimulant abuse.

[Neuropsychopharmacology 24:300-318, 2001] (C) 2001 American College of Neuropsychopharmacology. Published by Elsevier Science Inc.
KEY WORDS: Intravenous and intracranial selfadministration; Reward; Reinforcement; Trait anxiety; Stress; Cocaine; Mice

The reinforcing effect of cocaine has long been demonstrated in several species including humans, (Pickens and Thompson 1968; Woods and Schuster 1968; Deneau et al. 1969; Goldberg 1973; Fischman and Schuster 1982). However, in studies using monkeys as well as rats, not

From the Department of Neuropharmacology CVN-7, The Scripps Research Institute, La Jolla, California (VD, LHG, GFK); and Laboratoire de Neurosciences Cognitives, CNRS UMR 5807, Université de Bordeaux I, Talence, France (VD, PC).

Address correspondence to: L. H. Gold, CNS/CV Biological Research, Schering-Plough Research Institute, K-15-2 MS2600, 2015 Galloping Hill Rd., Kenilworth, NJ 07033 USA. Tel: 908.740.3476; Fax: 908.740.3294; E-mail: lisa.gold@spcorp.com

Received 28 March 2000; revised 1 August 2000; accepted 31 August 2000. all individual subjects exhibit acquisition of self-administration, and data from subjects that fail to acquire selfadministration are usually excluded (Davis and Smith 1987). Consistent with these observations, many humans experiencing psychostimulant drugs do not develop compulsive drug-seeking behavior (Siegel 1984; O'Brien et al. 1986). Recently, an increasing number of studies have investigated the biological basis of the vulnerability to drug abuse in outbred rats. From this work, it is possible to define a vulnerability profile based on a number of behavioral, neurochemical, and endocrinological features (Hooks et al. 1991; Piazza and Le Moal 1996). Importantly, traits associated with a vulnerable phenotype in rats, such as novelty-induced activity, can be compared to psychological dimensions measured in humans, such as novelty-seeking behavior (see Bardo et al. 1996). It is of special interest to note here that novelty- 
seeking and drug-seeking behaviors co-vary in humans as well as laboratory animals (Bardo et al. 1996). These behaviors are also expressed differentially in inbred strains of mice making these mice a potentially important model for further examining the relationship between behavioral traits, their underlying biological basis, and drug-seeking behavior (Crabbe et al. 1994).

Of particular interest in this context is the difficulty of demonstrating intravenous cocaine self-administration in BALB/cByJ mice (Deroche et al. 1997; Roberts et al. 1997; Yu et al. 1997), using doses known to maintain self-administration in C57BL/ 6 or several other strains (Carney et al. 1991; Grahame et al. 1995; Deroche et al. 1997; Rocha et al. 1998). This observation cannot be accounted for by pharmacokinetic differences (Ruth et al. 1988), capacity to learn operant tasks (Cazala 1976; Deroche et al. 1997; Heyser et al. 1997), or sensitivity to disruption of operant responding by acute cocaine (Heyser et al. 1997). However, BALB/cByJ mice have long been considered to be among the inbred strains showing high emotional reactivity, and BALB/cByJ neophobia has been proposed as a model of trait anxiety (Belzung and Berton 1997). BALB/cByJ exhibit, in fact, the highest stress-induced corticosterone levels among five other strains (Shanks et al. 1990) and show a hypersensitivity to corticotrophin-releasing factor(CRF) induced decreases in locomotor activity (Conti et al. 1994). BALB/cByJ mice also exhibit a strong increase in corticofrontal metabolism following introduction to a novel open field (Tassin et al. 1980) as well as foot shock-induced activity of mesocortical neurons (Hervé et al. 1979). Altogether, these data suggest that the high emotional reactivity profile of BALB/cByJ mice may contribute to the difficulty of establishing intravenous cocaine self-administration.

Knowing the factors that interfere with the sustained acquisition of cocaine self-administration in BALB/cByJ mice may reveal important clues to the problem of the biological basis of vulnerability to drug abuse. To this end, we further investigated the acquisition phase of intravenous cocaine self-administration in BALB/cByJ mice, using a low dose and habituation sessions. In an attempt to dissociate cocaine effects elicited peripherally or centrally that might compete with acute rewarding effects, we also studied the acquisition of intracranial self-administration behavior at the level of a reward-relevant brain region extensively involved in cocaine-induced reward: the nucleus accumbens (review in Bardo 1998).

\section{METHODS (EXPERIMENT I: INTRAVENOUS COCAINE SELF-ADMINISTRATION)}

\section{Subjects}

A total of 22 adult male mice of the BALB/cByJ strain (The Scripps Research Institute Breeding Colony) were used. Mice were housed 4/cage in Plexiglas cages $(28 \times$ $17 \times 11.5)$ with sawdust bedding changed weekly. At least 1 week before the surgery and throughout the intravenous self-administration (IVSA) study, animals were singly housed to protect catheterized subjects and mimic the maintenance conditions of mice used in the intracranial self-administration (ICSA) study. Colony temperature was maintained at $24^{\circ} \mathrm{C}$. Subjects were provided food ad libitum and maintained under conditions of a reverse light/dark cycle (lights on 22:00 h, lights off 10:00 h). The animals were 3 to 6 months of age (25-30 g) at the beginning of the experiments.

\section{Apparatus}

Catheter Construction. The chronic intravenous catheter for mice was similar to that described previously (Deroche et al. 1997). Briefly, one end of a 7-cm length of soft Silastic tubing (i.d. $0.30 \mathrm{~mm}$, o.d. $0.64 \mathrm{~mm}$ ) was immersed in Hemo-De solvent (Fisher Scientific, Pittsburgh, PA) to expand the tip for fitting to a 22-gauge steel cannula with a plastic screw-threaded pedestal (collar) and bent at a right angle. The cannula was then encased in dental cement with a piece of durable mesh secured to the bottom. The catheters were immersed in $70 \%$ ethanol for $20 \mathrm{~min}$ and then washed in $0.9 \%$ bacteriostatic saline before the surgical implantation. After implantation, the exposed tip of the external cannula was secured with a stopper consisting of a small piece of removable Tygon tubing ( $0.5 \mathrm{~mm}$ i.d./1.5 $\mathrm{mm}$ o.d.) closed at one end with monofilament and encased in a section of slightly larger copper tubing.

Catheter Implantation Surgery. The mouse was anesthetized with a halothane/oxygen vapor mixture and maintained at approximately $1.5 \%$ halothane delivered via a miniature nose-cone with tubes for vapor entry and exhaust to a ventilation system. Throughout the procedure, the animal was supported by a heating pad to prevent hypothermia. After shaving and application of $70 \%$ alcohol and iodine solution, incisions were made in the midscapular region as well as anteromedial to the forearm above the external right jugular vein. A catheter was passed subcutaneously from the dorsal incision to the ventral incision. Following isolation of the jugular vein, a 23-gauge needle was inserted into the vein $0.5 \mathrm{~cm}$ above the pectoral muscle to facilitate insertion of a 22-gauge needle modified to be used as a guide for the Silastic tubing. Once the tubing was inserted approximately $0.6 \mathrm{~cm}$ into the vein, the modified needle was removed, and the tubing was further inserted to the level of a small mark $(1.2 \mathrm{~cm}$ from the open tip of the Silastic). The catheter was then tied gently to the vein with two sutures (surgical silk 4-0; Ethicon). Approximately $0.01 \mathrm{ml}$ of physiological saline was flushed through the catheter to displace the blood and to sus- 
tain catheter patency by avoiding clotting. The catheter was capped with a Tygon stopper. Animals were allowed a minimum of 5 days recovery before the beginning of self-administration testing.

Catheter Evaluation and Maintenance. Methohexital sodium (Brevital $®$ ) is an ultrashort-acting barbiturate that, when flushed through the catheter, produces overt signs of sedation within seconds. Aqueous 1\% methohexital sodium was dissolved in $0.9 \%$ bacteriostatic saline to obtain a concentration of $5 \mathrm{mg} / \mathrm{ml}$. The Brevital test was performed once before the first self-administration session and once after every five self-administration sessions thereafter. At least $4 \mathrm{~h}$ after a cocaine self-administration session or $12 \mathrm{~h}$ before the next session, approximately $20 \mu \mathrm{l}$ of the solution was flushed through the catheter. Animals that showed no immediate signs of sedation were removed from the experiment.

The Self-Administration Unit. Twelve Plexiglas chambers $(14.9 \times 15.2 \times 18.3 \mathrm{~cm})$ each were located within larger boxes (Coleman coolers) equipped with exhaust fans that also functioned to mask background noise. Each chamber contained one wall with two small holes (0.9 $\mathrm{cm}$ diameter, $4.2 \mathrm{~cm}$ apart, $1.5 \mathrm{~cm}$ from the floor) equipped with photocell beams to detect responses. When the photocell in the hole defined as active was triggered by a nose-poke, the infusion pump (Razel ${ }^{\circledR}$ syringe pump with a $5 \mathrm{rpm}$ motor) delivered an infusion of $25 \mu \mathrm{l} / 5 \mathrm{sec}$ from a $10 \mathrm{ml}$ syringe. We have previously compared nose-poke and lever press operants for intravenous self-administration in mice and found little difference in acquisition or dose-effect curves (David et al. 1998b, see also Caine et al. 1999). The infusion volume delivered by this system was calibrated, and consistency in the volume of solution delivered was verified periodically. The volume delivered varied by $5-10 \%$ with each delivery. The syringe was connected via Tygon tubing to a swivel (Instech, Plymouth Meeting, PA). The infusion system was mounted outside the exterior box (cooler). Following infusion delivery, a timeout period lasting $20 \mathrm{sec}$ was initiated, during which further nose-pokes were recorded but did not result in additional infusions. A nose-poke in the other hole, defined as inactive, was without scheduled consequence at any time.

\section{Intravenous Cocaine Self-Administration Procedure}

Acquisition Study (Days 1-9). Self-administration sessions (1/day; 2 h each, 5 days/week) were conducted between 12:00 and 18:00 h. During the first session, the mice were placed into the chambers but were not connected to the injection system in order to habituate the mice to the apparatus. Cocaine was then made available under a fixed-ratio 1 (FR 1) schedule with a 20-sec time- out. A minimum of 20-25 injections/session were required for the schedule to be moved from FR 1 to FR 3 . All mice in this study met this criteria on the first day; therefore, an FR 3 schedule was used from the second drug session throughout the remainder of the experiment. Because previous studies have shown that higher doses of cocaine lead to a proportional decrease in selfadministration or even suppression of activity in this strain (Deroche et al. 1997; Yu et al. 1997) acquisition of self-administration was tested at the low dose of 200 $\mu \mathrm{g} / \mathrm{kg} / \mathrm{inj}$. Mice were tested for eight consecutive sessions (day 2-9) and acquisition was defined as: (1) three consecutive self-administration sessions in which the total number of injections (total cocaine intake) remained constant within $20 \%$ deviation from the mean of these sessions (stable responding); and (2) discrimination index (active nose-pokes/ total nose-pokes) $\geq$ $70 \%$ for 3 days. Out of the 22 subjects that started the experiment, 16 were tested under conditions of cocaine availability, the six remaining subjects were tested under conditions of saline availability (control group).

Effects of Diazepam (Days 10-14). From day 10, all the animals that did not reach both acquisition criteria $(n=15)$ were assigned to one of two groups. One group $(n=7)$ received a systemic injection of a low dose of diazepam $(0.5 \mathrm{mg} / \mathrm{kg}$, IP) $20 \mathrm{~min}$ before the self-administration session, while a second group $(n=8)$ received a vehicle injection instead. Group assignment was matched so that no pre-existing differences in the rate of responding or discrimination was observed before the anxiolytic treatment (Figure 1A). Control animals $(n=$ 6) receiving saline IV were also injected with diazepam. The dose of diazepam $(0.5 \mathrm{mg} / \mathrm{kg})$ was chosen: (1) to avoid nonspecific effects on the rate of responding; (2) because this low dose has no consistent effects on lateral hypothalamus self-stimulation in rats (Borisenko et al. 1996; Harris and Bielajew 1991) and does not induce place conditioning in rats or mice (Spyraki and Fibiger 1988; Borsini et al. 1993; Meririnne et al. 1999). A higher dose of diazepam, $1 \mathrm{mg} / \mathrm{kg}$, was tested in a few mice with the same results as presented.

\section{METHODS (EXPERIMENT II: INTRACRANIAL COCAINE SELF-ADMINISTRATION)}

\section{Animals and Surgery}

These experiments used 27 male mice of the BALB/ cByJ strain (Iffa-Credo, Lyon, France). At 12 weeks of age, they were housed individually with ad libitum access to food and water in a temperature-controlled room $\left(23^{\circ} \mathrm{C}\right)$ with a light-dark cycle $(12 \mathrm{~h} / 12 \mathrm{~h}$, light on at 8.00 A.M.) and sawdust bedding changed weekly. The animals were aged 3-4 months (27-30 g) at the beginning of the experiments. 


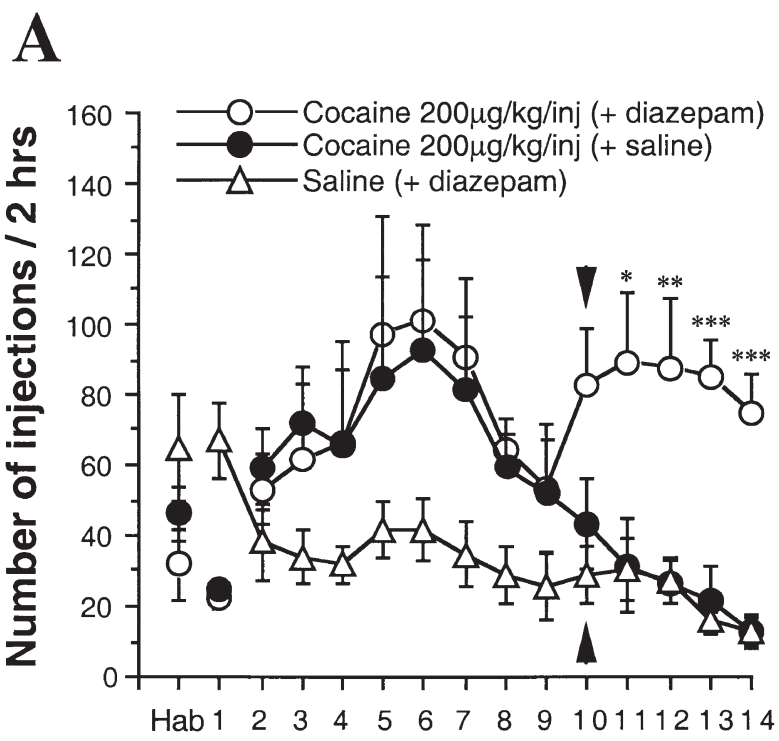

B

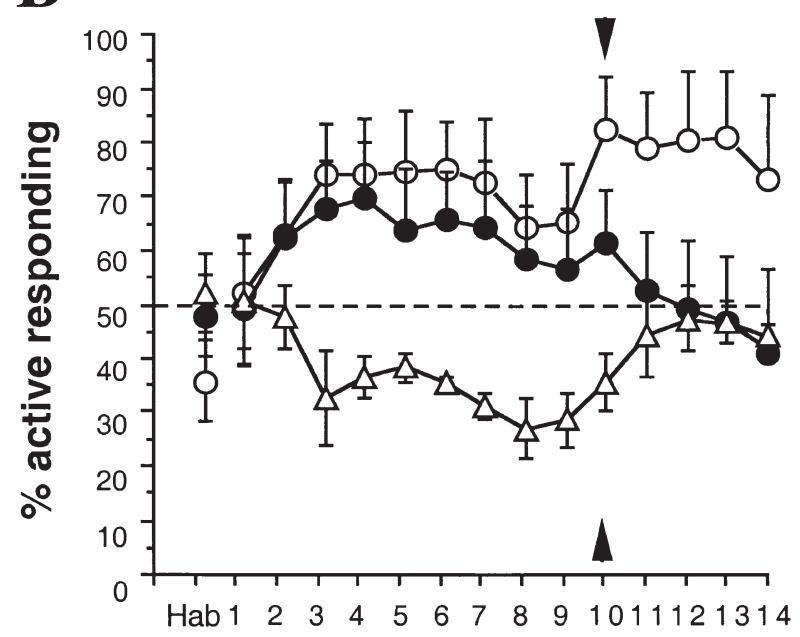

\section{Sessions}

Figure 1. Mean ( \pm S.E.M.) number of intravenous cocaine (200 $\mu \mathrm{g} / \mathrm{kg} /$ inj) self-injections (A) and discrimination index (B) recorded in animals with access to cocaine or the vehicle (controls, $n=6-5$ ). Sessions 1-9: cocaine alone $n=7$ [open circle] and $n=8$ [filled circle]. Sessions 10-14: cocaine + diazepam $0.5 \mathrm{mg} / \mathrm{kg}$, IP $n=7-4$ [open circle]; cocaine + saline $n=8-5$ [filled circle]; saline IV + diazepam IP $n=$ 5-4. ${ }^{*} p<.05,{ }^{* *} p<.01,{ }^{* * *} p<.001$ diazepam versus vehicle (saline IP).

The choice of the nucleus accumbens (NAc) as a target site was based on the following reasons: (1) it long has been demonstrated as a reward-relevant brain region; however, intracranial cocaine self-administration studies conducted in rats have led to inconsistent results (Goeders and Smith 1983, 1993; Carlezon et al. 1995; McKinzie et al. 1999); and (2) the involvement of this structure in the rewarding effects of cocaine in mice remains to be demonstrated.
Under deep sodium thiopental anesthesia $(90 \mathrm{mg} /$ $\mathrm{kg}$ ), the animals were implanted unilaterally and counterbalanced left or right with a guide-cannula (o.d. $0.460 \mathrm{~mm}$; i.d. $0.255 \mathrm{~mm}$ ) the tip of which was positioned either 1.5 (NAc group, $n=17$ ) or $2.3 \mathrm{~mm}(\mathrm{CPu}$ group, $n=10$ ) above the NAc. This second group was used to test the eventual diffusion, in a dorsal direction, of cocaine when infused into the NAc (Wise and Hoffman 1992). In this group, cocaine was injected just above the NAc, into the anterior part of the caudate putamen nucleus ( $\mathrm{CPu}$ group). The stereotaxic coordinates used were the following: NAc: $1.70 \mathrm{~mm}$ anterior to the bregma $(\mathrm{AP}) ; \pm 1.60 \mathrm{~mm}$ lateral to the sagittal line (L); $2.40 \mathrm{~mm}$ vertically below the surface of the skull (V); CPu: AP + $1.70 \mathrm{~mm}$; $\pm 1.60 \mathrm{~mm}$; V + 1.60 $\mathrm{mm}$. In both groups, the guide-cannula was lowered at a $12^{\circ}$ angle in order to avoid the lateral ventricle. The incisor bar was level with the interaural line. Mice were allowed to recover from surgery for at least 1 week.

\section{Intracranial Self-Injection Procedure}

On each day of the experimental period, a stainlesssteel injection cannula (o.d. $0.229 \mathrm{~mm}$, i.d. $0.127 \mathrm{~mm}$ ) was inserted into either the NAc or the $\mathrm{CPu}$ and was held in a fixed position by means of a small connector. The injection cannula was connected by flexible polyethylene tubing to the micro-injection system, which housed a $5 \mu$ l Hamilton ${ }^{\circledR}$ syringe. The tip of the injection cannula projected beyond the guide-cannula by 1.5 $\mathrm{mm}$. By interrupting one photocell beam in the Y-maze (see behavioral procedure) mice could obtain an infusion (injection of cocaine $\mathrm{HCl}$ dissolved in ringer solution). Intracerebral injections were carried out using an automatic computer-controlled apparatus that provided via a microvernier system, a precise and highly reproducible descent of the microsyringe piston. Each self-injection $(50 \mathrm{nl})$ lasted $4 \mathrm{sec}$. Flow of solutions was verified by monitoring the fluid volume in the Hamilton syringe before and after testing each subject. The movement of the animals in the Y-maze was detected by an optical system. This information was transmitted to a microcomputer that, in turn, rotated the injector in the same direction as the animal's movement. This process avoided twisting of the flexible tubing, and, consequently, self-administration could be studied in freely moving mice.

\section{Behavioral Protocol}

Self-administration behavior was studied in a gray Plexiglas Y-maze, the two arms of which were separated by an angle of $90^{\circ}$. The stem and the arms were $31-\mathrm{cm}$ long and 12-cm high. The starting box $(14 \times 8 \mathrm{~cm})$ was separated from the stem by a sliding door. Sliding doors were located at the entrance of each arm. A pho- 
toelectric cell was situated $6 \mathrm{~cm}$ from the end of each arm. By interrupting the photocell beam in one of the two target arms, mice could trigger an injection of cocaine $\mathrm{HCl}$ dissolved in Ringer solution; the other arm being neutral (no injection).

During a first habituation session no injection was delivered. During the following sessions, to begin a trial, a mouse was placed in the start box, and after 1 min the doors to the stem and target arms were opened. In each group, half of the animals were assigned to go to the right arm to trigger the injection of cocaine; whereas, the remainder were assigned to the left arm. Each daily session was composed of 10 trials separated by a 1-min intertrial interval; therefore, a maximum of 10 injections could be obtained by each subject per daily session. Chance performance was reflected by five injections out of 10 trials. During the first four trials of the first session, if an animal made an "error" in choosing the neutral arm, it was immediately allowed access to the arm enabling an injection of cocaine. From the fifth trial onward, following arm selection, the chosen arm was closed off to prevent movement into the other arm. After a 10-sec confinement, the mouse was removed and replaced directly into the start box for the following trial.

1. During the acquisition phase, the number of selfinjections per daily session was recorded and automatic equipment, triggered by opening the door to the stem, recorded the latency to enter the reinforced arm (response latency) or the neutral arm for each subject. Acquisition of the self-administration response was tested over seven daily sessions using two doses of cocaine in separate groups of mice implanted in either the NAc (10 ng [ 30 pmol; $n=6$ ] or $50 \mathrm{ng}$ [150 pmol; $n=6]$ ) or CPu (30 pmol; $n=5$ and $150 \mathrm{pmol} ; n=5)$. An additional group of NAc mice $(n=5)$ received only vehicle. These animals exhibited random choices and self-injection latencies similar to controls subjects receiving polyionic Ringer solution at the level of numerous other brain regions (David and Cazala 1994). Therefore, no further ICSA control groups were used in the present study.

2. The second phase was conducted to verify the pharmacological specificity of the ICSA behavior and to test the involvement of a dopamine D2-receptor mechanism. Sulpiride was used, because, as an atypical neuroleptic, it is likely to produce a more specific blockade of the mesolimbic versus extrapyramidal system (White and Wang 1983). Starting on the 8th session, those subjects in the cocaine $50 \mathrm{ng}$ group that had fully met self-administration criteria, defined as at least seven choices out of 10 trials of the cocaine-reinforced arm during 3 consecutive days, were then injected systemically $30 \mathrm{~min}$ before the self-administration session with the dopaminergic D2 antagonist sulpiride (50 mg/ kg IP). For the con- trol group (mice implanted in the NAc but receiving only Ringer during the acquisition phase), cocaine was now substituted (50 $\mathrm{ng}$ ).

3. During a third phase, which lasted for a further 3 days, the pretest injection of sulpiride was replaced by an injection of the vehicle only.

4. Finally, because all the subjects that had fully acquired the self-administration response using the 10 ng cocaine dose developed shuttling behavior contributing to an increase in the self-injection latency over days, two more sessions were conducted in these animals during which one half of the subjects received an injection of diazepam $(1 \mathrm{mg} / \mathrm{kg}, \mathrm{IP}) 20$ min before the session, while the other half received the vehicle (session 8). The following session, these treatments were reversed for each subgroup (session 9). The rationale for using a higher dose of diazepam in the intracranial self-administration experiment was to optimize the observation of a behavioral effect while being still able to control for motor effects by analyzing the running time in the Y-maze. The dose of $1 \mathrm{mg} / \mathrm{kg}$ has been reported to be the highest dose of diazepam that can be used in BALB/cByJ mice without inducing motor slowing or sedation (Borde et al. 1998).

\section{HISTOLOGY}

At the end of the experimental period, the animals were sacrificed with an overdose of thiopental. The head was removed, with the guide-cannula attached, and placed into $10 \%$ formol for $72 \mathrm{~h}$. The guide-cannula was withdrawn, and the brain was dissected and placed in a solution of formol containing 30\% sucrose for a further week. Brains were frozen and cut in a microtome to provide $60 \mu \mathrm{m}$ frontal sections that were stained using $0.1 \%$ thionin to identify the injection site.

\section{DRUGS}

Cocaine hydrochloride was dissolved in polyionic Ringer for intracranial injections. A predissolved preparation of $\left( \pm\right.$ )-sulpiride (Dogmatil ${ }^{\circledR}$, injectable, Synthelabo group, Meudon, France) was used by dilution in physiological saline $(\mathrm{NaCl} 0.9 \%)$ to the required final concentration. The $\mathrm{pH}$ of the injected solution was 5.9. A predissolved preparation of diazepam (Valium ${ }^{\circledR}$, Roche, France) was diluted in physiological saline to the required final concentration. For systemic administration, drug and vehicle were injected IP in a volume of $0.10 \mathrm{ml} / 10 \mathrm{~g}$ body weight, respectively $20 \mathrm{~min}$ and 30 min before behavioral testing for diazepam and sulpiride. Brevital@ Sodium (methohexital sodium; Eli Lilly, Indianapolis, IN) was dissolved in saline $0.9 \%$. 


\section{SATISTICAL ANALYSES}

Two-way analyses of variance (ANOVAs) with one repeated factor (session/day) were used to measure between-groups differences for drug, hole, discrimination index, or ICSA injection site, as well as the interaction of group $\times$ sessions. Furthermore, post-hoc analysis employed Scheffe's $F$ test corrected for multiple comparisons. One-way ANOVA was used for the withinsubjects repeated factor session/day, to analyze the evolution of self-administration (number of self-injections) for a particular group (Winer 1971). Animals that did not fully complete a given experiment were excluded from the statistical analysis. An unpaired Student's $t$ test was used to compare the mean of active or inactive responding in cocaine versus saline IV groups, and a paired test was used to compare the mean of ICSA and self-injection latencies in the group receiving the $10 \mathrm{ng}$ cocaine dose into the NAc during two consecutive sessions following acquisition (saline vs. diazepam pretreatment). A significance level of $p<.05$ was used for all statistical analyses.

\section{ETHICAL STATEMENT}

All surgical and experimental procedures were in accordance with official French Regulations for the Care and Use of Laboratory Animals and the Institutional Animal Care and Use Committee of The Scripps Research Institute.

\section{RESULTS (EXPERIMENT I: INTRAVENOUS COCAINE SELF-ADMINISTRATION)}

\section{Acquisition Study (Days 1-9)}

Saline-Injected Animals. Subjects in the control group having only access to saline (from day 1 to day 9: $n=6-4)$ did not show any evidence of self-administration behavior. None of them achieved stability in the number of injections, and this parameter decreased progressively over the acquisition period from day 1 to 5 as reflected in a one-way repeated measures ANOVA for session: $\mathrm{F}_{4,12}=5 p<.01$ (Figure 1A). Evaluation of the discrimination index in control mice revealed that unlike that observed in the ICSA experiments below, discrimination of active and inactive holes by control mice was lower than the theoretical chance level of $50 \%$ (Figure 1B). In fact, control mice poked significantly more in the inactive than in the active hole over the FR3 sessions $2-9$, as confirmed by a main effect of hole in a two-way ANOVA $\left(\mathrm{F}_{1,6}=18.53 p<.01\right)$. Increases in inactive responding have been related to extinction of intravenous self-administration in mice and rats (Rocha 1999; McBride et al. 1999).
Cocaine Availability. When mice with cocaine versus saline availability were compared for the number of infusions earned, a two-way ANOVA confirmed the absence of a group effect (saline vs. cocaine groups) or group $\times$ day interaction, and revealed only a significant main effect of day $\left(\mathrm{F}_{7,133}=2.2 p<.05\right)$. Of the 16 animals having access to cocaine infusions ( $200 \mu \mathrm{g} / \mathrm{kg} / \mathrm{inj})$ for 8 days, only one met the acquisition criteria. The others failed to achieve both the requirement for stability in the number of injections and a discrimination index of $>70 \%$. However, results in the 15 remaining subjects resembled a biphasic curve with a strongly positive initial reaction during the first five sessions (with subjects earning up to 100 injections/session), quickly followed by a steady decrease in the number of injections earned (one-way ANOVA repeated measures on session: $\mathrm{F}_{7,140}=2.32 p<$ .02) (Figure 1A). Interestingly, the pattern of cocaine intake was very irregular across days and between subjects during the acquisition period (within-group variability: $\mathrm{F}_{20,147}=17.14 p<.001$ ). There was no difference in exploratory "active" or "inactive" responding during the initial habituation session between saline and cocaine IV groups (mean number of active nose-pokes: $\mathrm{t}(19)=0.6 \mathrm{~ns}$; inactive nose-pokes: $\mathrm{t}(19)=0.04 \mathrm{~ns})$. Once cocaine was made available, cocaine-injected animals displayed a higher preference for the active hole than mice having only access to saline over the eight acquisition sessions on an FR3 schedule. Analysis of discrimination index across sessions resulted in a main effect of group $\left(\mathrm{F}_{1,15}=8.5, p<.02\right)$.

\section{Effect of Diazepam on Intravenous Cocaine Self- Administration (Days 10-14)}

For 5 days (from day 10 to 14), a dose of $0.5 \mathrm{mg} / \mathrm{kg}$ of diazepam was injected IP $20 \mathrm{~min}$ before the sessions. Treatment with the anxiolytic dramatically improved intravenous cocaine self-administration behavior. In contrast to the rapid decrease in the total number of injections in a 2-h session observed in the subjects receiving vehicle, this parameter increased or remained high for the 5 successive days in diazepam-pretreated animals (main effect of group: $\mathrm{F}_{2,10}=11.7 p<.01$ ). The discrimination between the active and inactive hole also tended to be improved in diazepam-pretreated animals, an effect that did not reach significance because of the presence of animals showing a preference for either the active or inactive hole in both groups (Figure 1B). The appearance of a slight increase in relative responding to the active hole in the control group (saline IV) with diazepam was not statistically significant and seemed to start before the treatment, likely reflecting an instability of responding associated with saline availability. The same dose of diazepam $(0.5 \mathrm{mg} / \mathrm{kg})$ did not have any effect on other aspects of operant responding (number of injections and total responding), suggesting 
that the increased number of cocaine injections administered during the anxiolytic treatment was not attributable to a nonspecific effect of diazepam to increase response rates (Figure 1). Analysis of individual data further revealed that diazepam had a similar effect on cocaine self-administration regardless of the level of exposure during the acquisition phase (Figure 2).

Within-session analysis of the first diazepam treatment day revealed that diazepam increased the cocaine intake (= total number of injections/session) by decreasing the interinjection interval shown as the slope of the cumulative reinforcers per unit-time curve in Figure 3 (main effect of group $\mathrm{F}_{2,17}=4.4 p<.05$; time $\mathrm{F}_{17,187}$ $=43.2 p<.0001$; and group $\times$ time interaction during the first diazepam session $\mathrm{F}_{22,187}=3.1 p<.0001$ ). For the last acquisition session immediately before the first diazepam treatment day, there was no difference between the animals to be treated the next day with diazepam or saline, in either cocaine intake or pattern of self-administration (main effect of group $\mathrm{F}_{2,17}=0.7 \mathrm{~ns}$ and group $\times$ time interaction: $\mathrm{F}_{22,187}=0.6 \mathrm{~ns}$ ).

\section{RESULTS (EXPERIMENT II: SELF-ADMINISTRA- TION OF COCAINE INTO THE NAC OR THE CPu)}

\section{Ringer Group}

No discrimination was observed between the two arms of the Y-maze when only vehicle (Polyionic Ringer) was available for intra-accumbens self-injections (one-way
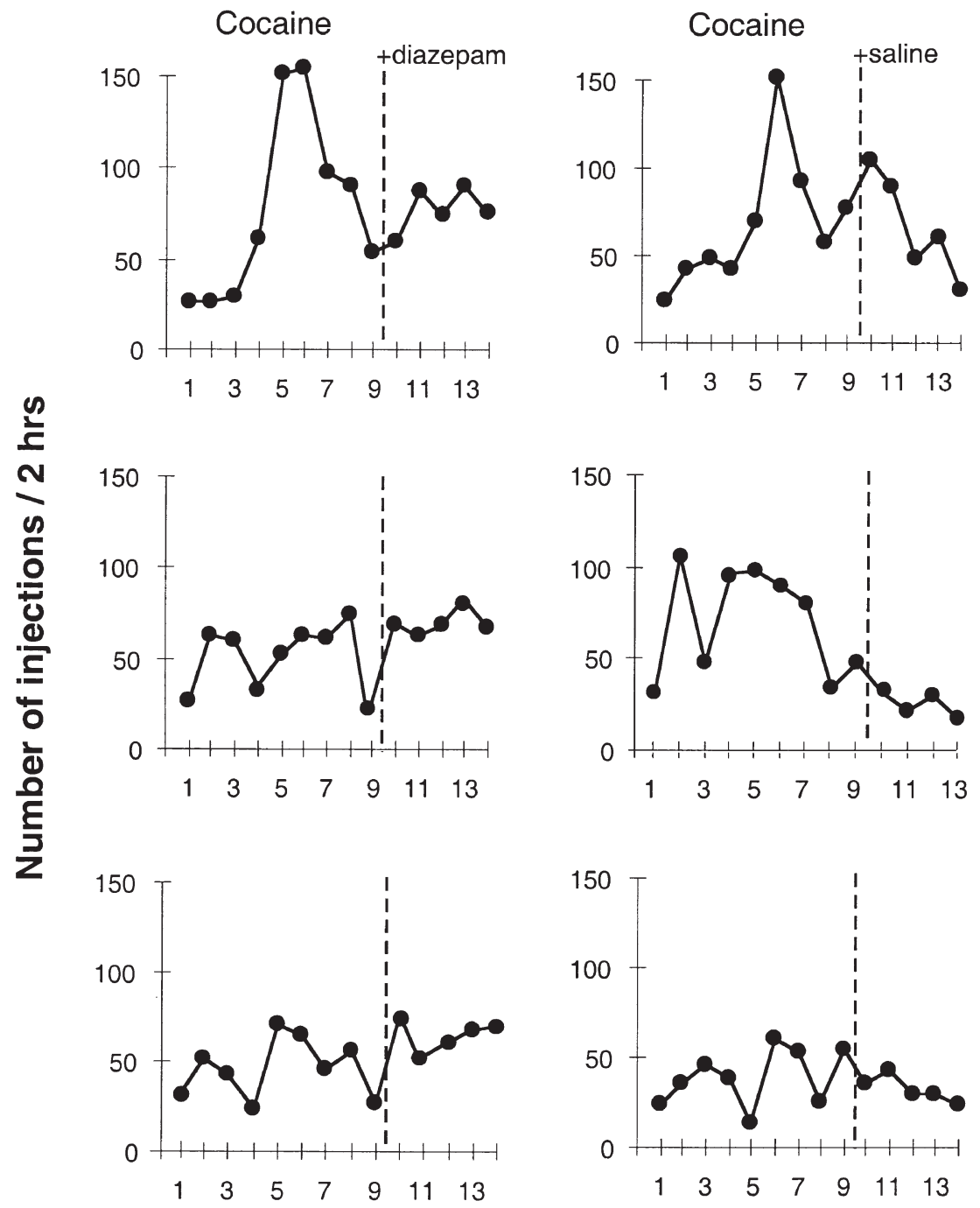

\section{Sessions}

Figure 2. Individual performances for the number of intravenous cocaine $(200 \mu \mathrm{g} / \mathrm{kg} / \mathrm{inj})$ self-injections in representative animals ( 3 diazepam +3 saline) during training sessions (1-9), and after presession treatment with either diazepam $0.5 \mathrm{mg} / \mathrm{kg}$ (sessions 10-14, left) or saline (right). These six animals are representative of the full range of responses observed in each group. 
A

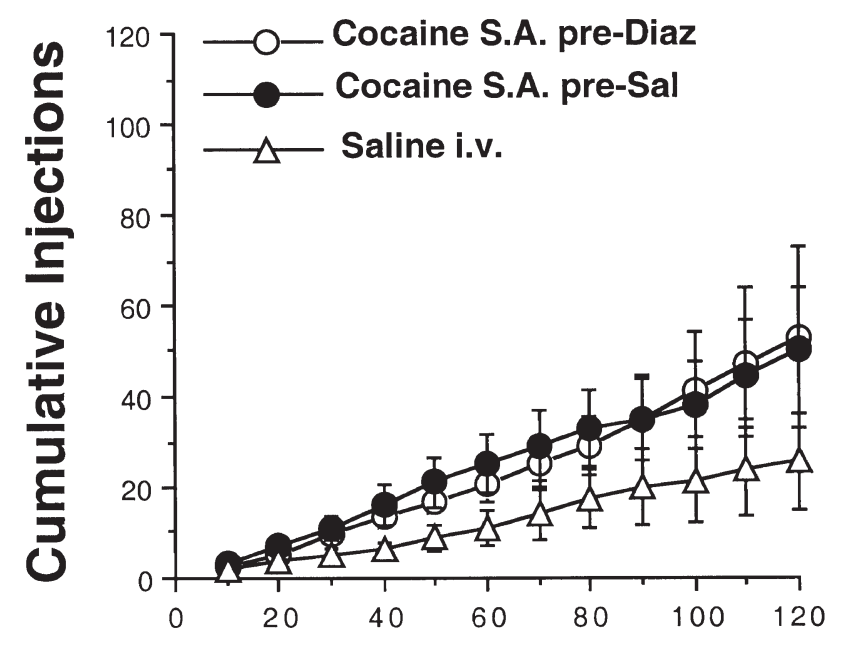

B First diazepam session

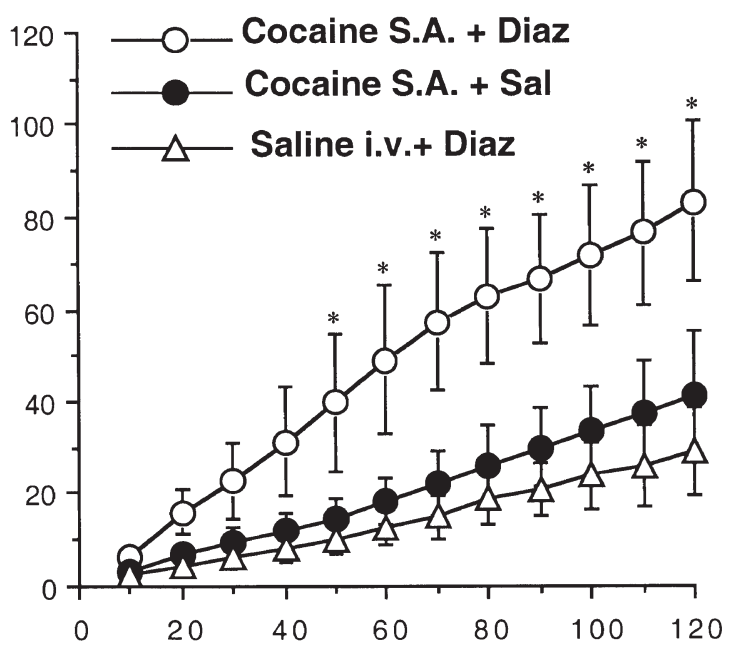

\section{Time (min)}

Figure 3. Within-session effects of diazepam $(n=7)$ and saline $(n=8)$ IP injections on intravenous cocaine self-administration. (A) represents the cumulative number of injections during the last acquisition session of cocaine self-administration in both groups before treatment. (B) represents the cumulative number of injections during the cocaine self-administration session on the first day of diazepam treatment $\left(0.5 \mathrm{mg} / \mathrm{kg}\right.$, IP). ${ }^{*} p<.05$, signifcantly different from controls (saline IP).

ANOVA with repeated measures on session: $\mathrm{F}_{6,24}=$ $0.511 \mathrm{~ns}$ ) (Figure 4A). This demonstrated the absence of nonspecific (i.e., mechanical) stimulating effects of the microinjection system and confirms previous observations (David and Cazala 1994; David et al. 1998a). A clear self-administration response occurred when cocaine (50 ng) was substituted for the vehicle (Figure 4A, right). A one-way repeated measures ANOVA on the evolution of arm choice over the 14 sessions yielded a significant main effect of session: $\mathrm{F}_{11,44}=13.8 p<.0001$. Post-hoc analysis indicated significantly increased choices of the cocaine-reinforced arm starting from the second day following cocaine substitution (Scheffe $F$ test, $p<.001)$.

\section{Cocaine Groups}

Dose of $10 \mathrm{ng}(30 \mathrm{pmol})$. At this low dose, only animals receiving injections into the NAc discriminated between the two arms of the maze and regularly selfadministered cocaine. The same dose of the drug, when injected $0.8 \mathrm{~mm}$ above the NAc injection sites $(\mathrm{CPu}$ group) did not seem to have any rewarding effect, the subjects in this group behaved like control animals (Figure 4A). Analysis of arm choices in Ringer, Nac, and $\mathrm{CPu}$ groups revealed a main effect of group: $\mathrm{F}_{2,13}=46.2$ $p<.0001$, main effect of session: $\mathrm{F}_{6,78}=4 p<.01$ and group $\times$ session interaction: $\mathrm{F}_{12,78}=2.3 p<.01$ ).

Additional information was obtained through analysis of the injection latencies (Figure 4B). This parameter was much shorter in the cocaine-injected animals than in the Ringer group. As typically observed in vehicleinjected animals (David and Cazala 1994; David et al. 1998a), latencies progressively increased over days, a phenomenon likely to be related to the loss of motivation to trigger the injection. Interestingly, the opposite was observed in the $\mathrm{CPu}$ group. These results are supported by a significant main effect of group $\left(\mathrm{F}_{2,13}=16.7\right.$ $p<.001)$, and day $\left(\mathrm{F}_{6,78}=5.7 p<.0001\right)$ and a group $\times$ day interaction $\left(\mathrm{F}_{12,78}=12.4 p<.0001\right)$. The decrease in latency to trigger the injection over days in the $\mathrm{CPu}$ group presumably reflects a nonspecific effect, because the same subjects also were faster to enter the neutral arm (latency [sec]: day 1: $156.8 \pm 22 ; \mathrm{d} 2: 117.3 \pm 37$; d3: $100.2 \pm 21 ; \mathrm{d} 4: 67.3 \pm 14 ; \mathrm{d} 5: 71 \pm 13 ; \mathrm{d} 6: 62.4 \pm 8 ; \mathrm{d} 7$ : $\left.45.7 \pm 9 ; \mathrm{F}_{6,24}=4.93 p<.002\right)$. Interestingly, within-session analyses using a two-way ANOVA comparing the time to complete the first and last trials (trial factor) over the seven acquisition sessions (session factor) revealed that the time to complete the last trial was significantly longer (main effect of trial: $\mathrm{F}_{1,8}=11.61 p<.01$; with no main effect of session or trial $\times$ session interaction) (Figure 5). The time to complete the first trial varied significantly over days, decreasing on days 3 and 6 $\left(\mathrm{F}_{6,24}=2.6 p<.05\right)$.

In the NAc group injection latencies remained low and stable during the first three sessions, but increased over the following four sessions (shown in Figure 4B) and confirmed by a significant simple effect of session on this parameter $\left(\mathrm{F}_{6,30}=15.4 p<.0001\right)$. NAc mice pro- 

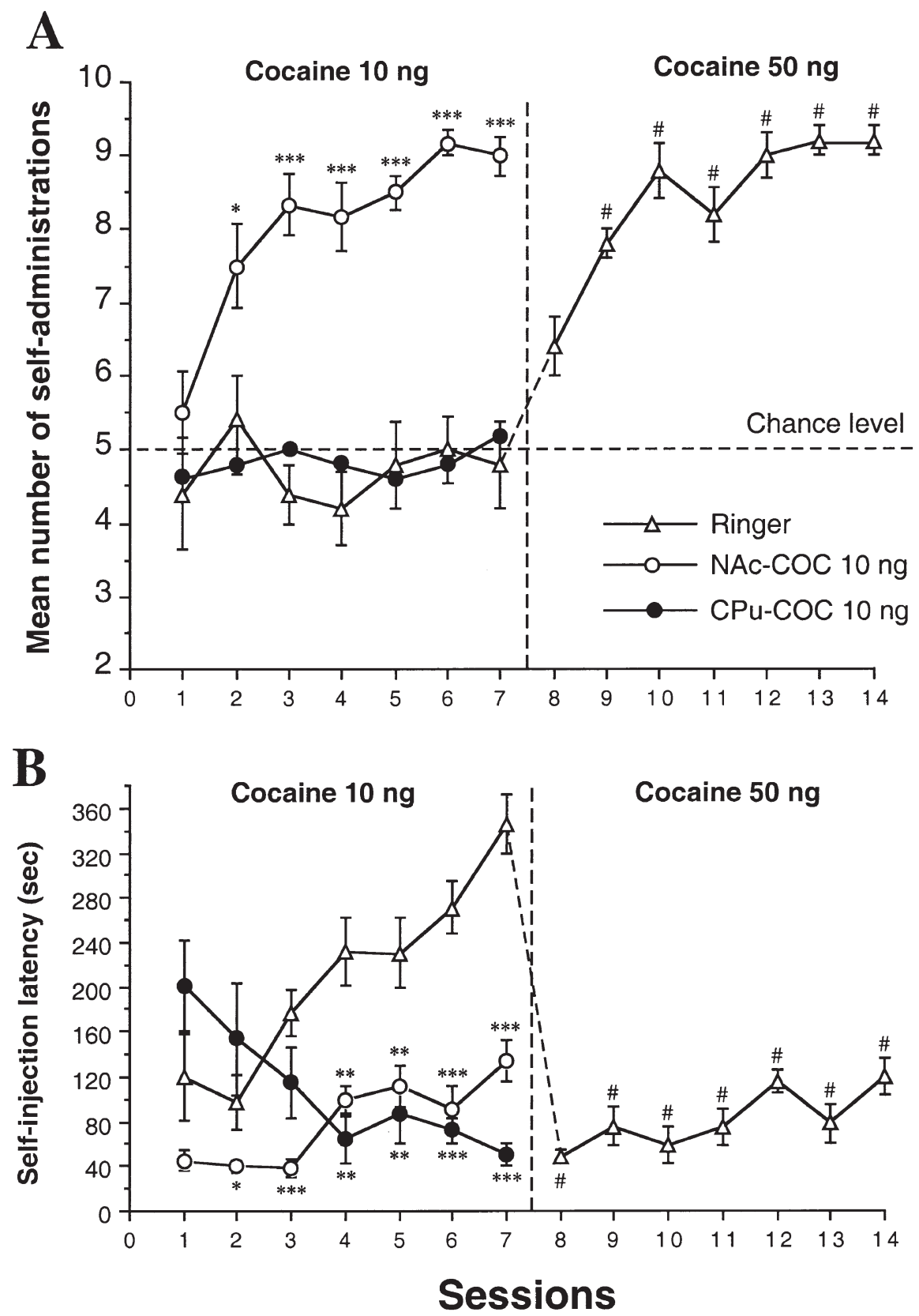

Figure 4. Mean ( \pm S.E.M.) number of self-administrations (A) and self-injection latency (B) recorded in animals injected with a dose of $10 \mathrm{ng}$ of cocaine into the NAc or the $\mathrm{CPu}$ or receiving the vehicle (Ringer solution, sessions $1-7$ ) and the dose of $50 \mathrm{ng}$ of cocaine into the NAc (sessions 8-14). ${ }^{*} p<.05,{ }^{* *} p<.01,{ }^{* * *} p<.001$ comparison with vehicle. \#, significantly different from the last acquisition session.

gressively hesitated to self-administer cocaine over the acquisition sessions and exhibited a shuttling behavior between the start box and the reinforced arm before triggering each injection. Despite this phenomenon, subjects in this group remained significantly faster than control (Ringer) mice (comparison of cocaine and Ringer main effect of group: $\mathrm{F}_{1,9}=29.6 p<.001$ ). Within-session analyses using a two-way ANOVA comparing the time to complete the first and last trial (trial factor) over the seven acquisition sessions (session factor) yielded a main effect of trial: $\mathrm{F}_{1,9}=25.06 p<.001$; a main effect of session: $\mathrm{F}_{6,54}=4.57 p<.001$; and a trial $\times$ session interaction; $\mathrm{F}_{6,54}=5.16 p<.001$. It is of interest to note that, similarly to injection latencies, evolution of the time to complete the last trial over the seven acquisition sessions displayed an opposite pattern in NAc and $\mathrm{CPu}$ animals (Figures 4 and 5); that is, decreasing in $\mathrm{CPu}$ mice, while increasing dramatically in NAC animals because of the progressive expression of retreat behavior. This observation is supported by a strong interaction when 
NAc, cocaine $10 \mathrm{ng}$
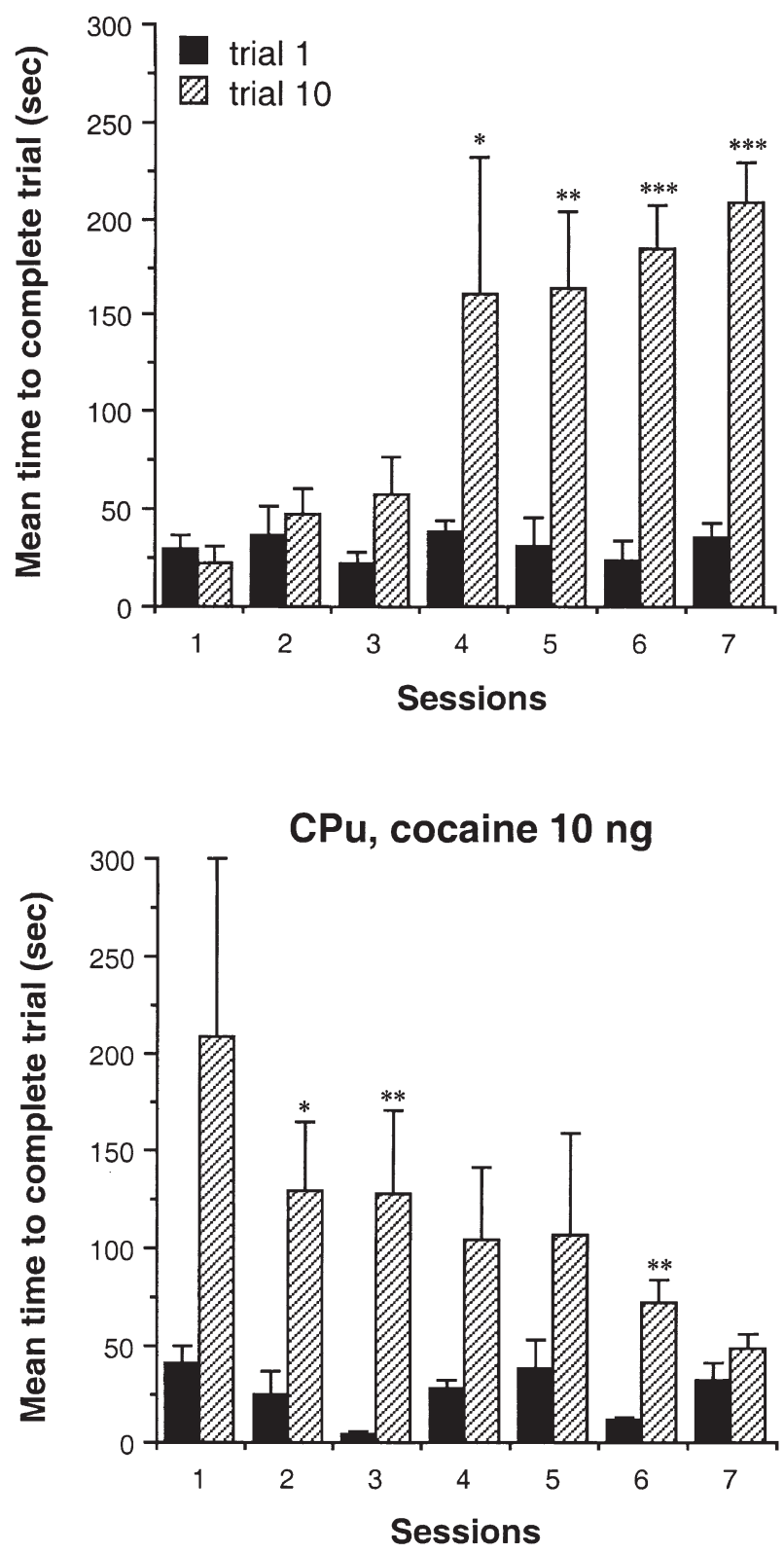

Figure 5. Mean value of the latency (sec \pm S.E.M.) to complete the first and last trial in NAc and CPu animals during acquisition of cocaine self-administration (10 ng). This parameter is different from self-injection latencies in that the time to complete the trial was analyzed whether an injection occurred or not. ${ }^{*} p<.05,{ }^{* *} p<.01,{ }^{* * *} p<.001$ : comparison of the latency to complete the first versus the last trial for each group during each session (Scheffe $F$ test).

the evolution of this parameter was compared between both groups (two-way ANOVA group $\times$ session interaction: $\left.\mathrm{F}_{6,48}=4.58 p<.001\right)$.

Dose of $50 \mathrm{ng}(150 \mathrm{pmol})$. Again, only mice receiving cocaine microinjections into the NAc learned to enter the reinforced arm preferentially; whereas, no discrimination between the two arms of the maze was observed in the $\mathrm{CPu}$ group, resulting in significant main effects of group comparing Ringer, NAc and $\mathrm{CPu}$ animals $\left(\mathrm{F}_{2,13}=73.6 p<\right.$ $.0001)$ and session $\left(\mathrm{F}_{6,78}=3.6 p<.01\right)$ (Figure 6A). As for the dose of $10 \mathrm{ng}$, injection latencies were much shorter in $\mathrm{NAc}$ and $\mathrm{CPu}$ than in Ringer animals (main effect of group: $\mathrm{F}_{2,13}=24.8 p<.0001$, Figure $6 \mathrm{~B}$; Ringer subjects are depicted in Figure 4). This parameter progressively increased over the seven acquisition sessions in the mice self-injecting the $50 \mathrm{ng}$ dose into the NAc, while decreasing until session three and increasing thereafter in the $\mathrm{CPu}$ group (main effect of session $\mathrm{F}_{6,78}=24.4 p<.0001$ and group $\times$ session interaction $\mathrm{F}_{12,78}=8.8 p<.0001$ ). Within-session analyses of the time to complete the first versus last trial revealed a pattern similar to the one observed with the 10-ng dose (data not shown).

Effects of Systemic Injections of Sulpiride $(50 \mathrm{mg} /$ $\mathrm{kg}$ ). The self-administration of cocaine into the NAc was highly sensitive to pretreatment (30 min before the session) with IP injection of $50 \mathrm{mg} / \mathrm{kg}$ of the selective dopaminergic D2 antagonist. Subjects that had previously acquired the ICSA response (cocaine dose of $50 \mathrm{ng}$ ) gradually lost the discrimination, reaching chance level within 5 days (extinction, see Figure $6 \mathrm{~A} ; \mathrm{F}_{4,20}=4.54 p<.01$ ). At the same time, self-injection latencies increased over the five extinction sessions $\left(\mathrm{F}_{4,20}=5.42 p<.01\right.$; Figure $\left.6 \mathrm{~B}\right)$.

Replacement of Sulpiride by $\mathrm{NaCl}$. Following extinction, the replacement of the systemic injection of sulpiride with an injection of physiological saline during three consecutive sessions resulted in the re-emergence of self-administration of the 50-ng dose of cocaine into the NAc (one-way repeated measures ANOVA for sessions $\left.12-15: \mathrm{F}_{3,15}=521.6 p<.0001\right)$. The choice of the cocaine-associated arm was significant from the first reacquisition day (Scheffe $F$ test, $p<.001$; Figure 6). Thus, the sulpiride-induced extinction did not result from a lesion related to the daily insertion of the cannula, or from the systemic injection procedure per se, because the ICSA response was restored when sulpiride was replaced by isotonic $\mathrm{NaCl}$.

Effects of Diazepam $(1 \mathrm{mg} / \mathrm{kg})$ on the Self-Administration of Cocaine into the NAc. The shuttling behavior that contributed to the increase in the time to trigger injection observed during the acquisition of cocaine self-administration resembled the "retreat behavior" previously described in rats self-administering cocaine intravenously in a straight alley runway (Ettenberg and Geist 1991). This behavior has been hypothesized to result from the conflicting (appetitive/aversive) properties of the drug and was shown to be sensitive to anxiolytic treatment. To test this hypothesis, at the end of acquisition, we pretreated the animals self-injecting the 10-ng dose of cocaine with systemic diazepam (1 $\mathrm{mg} / \mathrm{kg}, \mathrm{IP}$ ) or $\mathrm{NaCl} 0.9 \%$. Diazepam did not modify 

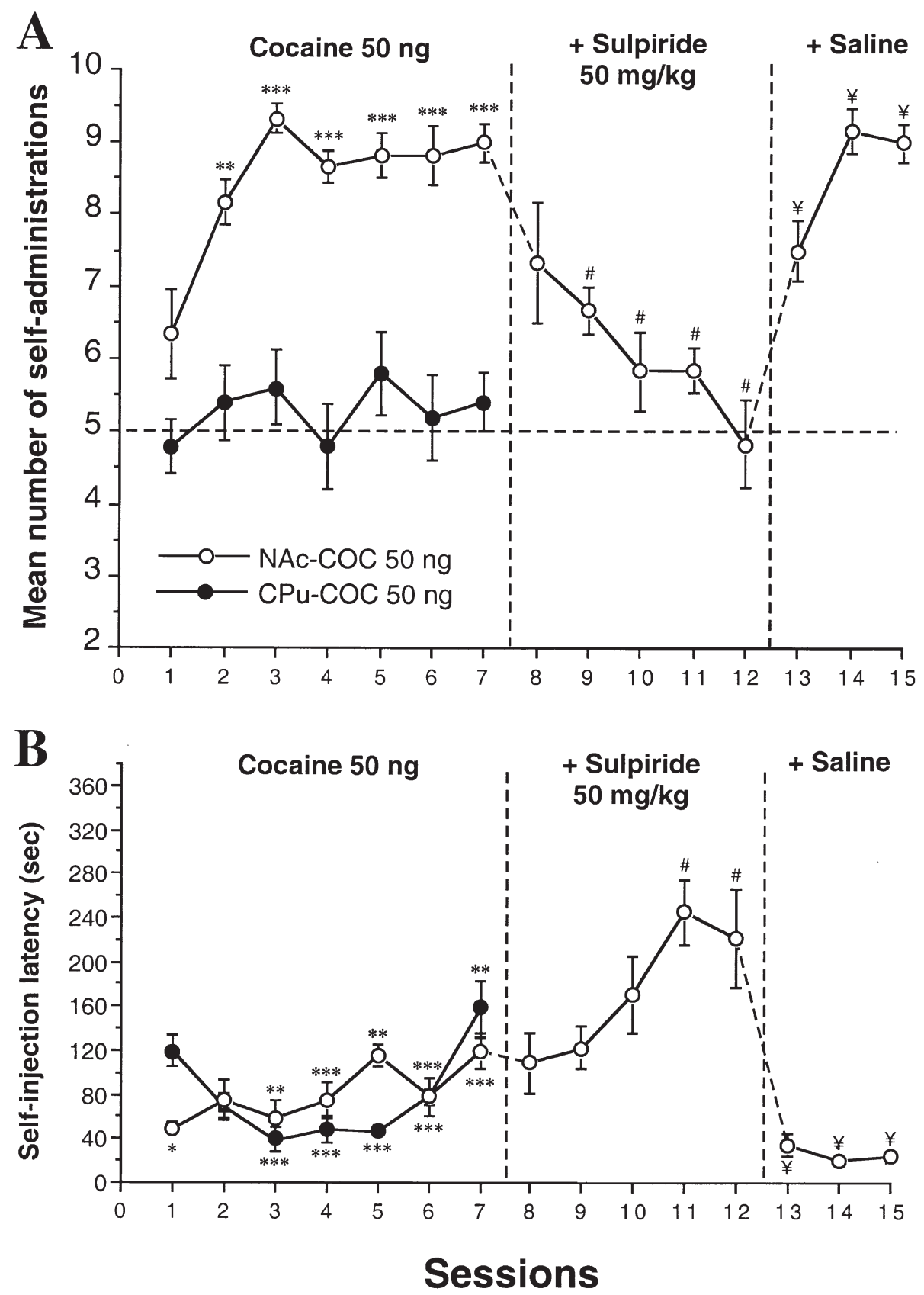

Figure 6. Mean ( \pm S.E.M.) number of self-administrations (A) and self-injection latency (B) recorded in animals injected with a dose of $50 \mathrm{ng}$ of cocaine into the NAc or the CPu (sessions 1-7: cocaine alone; sessions 8-12: cocaine and sulpiride 50 $\mathrm{mg} / \mathrm{kg}$ IP; sessions 13-15: cocaine and vehicle $\mathrm{NaCl} 0.9 \%) .{ }^{*} p<.05,{ }^{* *} p<.01,{ }^{* * *} p<.001$ comparison with vehicle. \#, significantly different from the last acquisition session. $¥$, significantly different from the last extinction session.

the choice of the cocaine-reinforced arm but almost completely abolished shuttle behavior, thereby decreasing the injection latency (paired Student's $t$ test comparing saline versus diazepam: $\mathrm{t}(5)=7.13 p<$ .001) (Figure 7).

\section{Histological Control}

Intracranial injection sites were precisely located by following the track of the injection cannula in both experi- mental and control subjects. Histological analysis revealed that cannulae of animals implanted into the NAc were located in the shell region of the structure (Figure 8) (Franklin and Paxinos 1997). It may be noted that for two animals of the $\mathrm{CPu}$ group, the injection site was located at the dorsal border of the $\mathrm{CPu}$ /core region of the NAc. Figure 9 shows a typical injection site in the NAc and $\mathrm{CPu}$. The scatter of the cannula tracks was identical in the different groups studied. Based on histological 

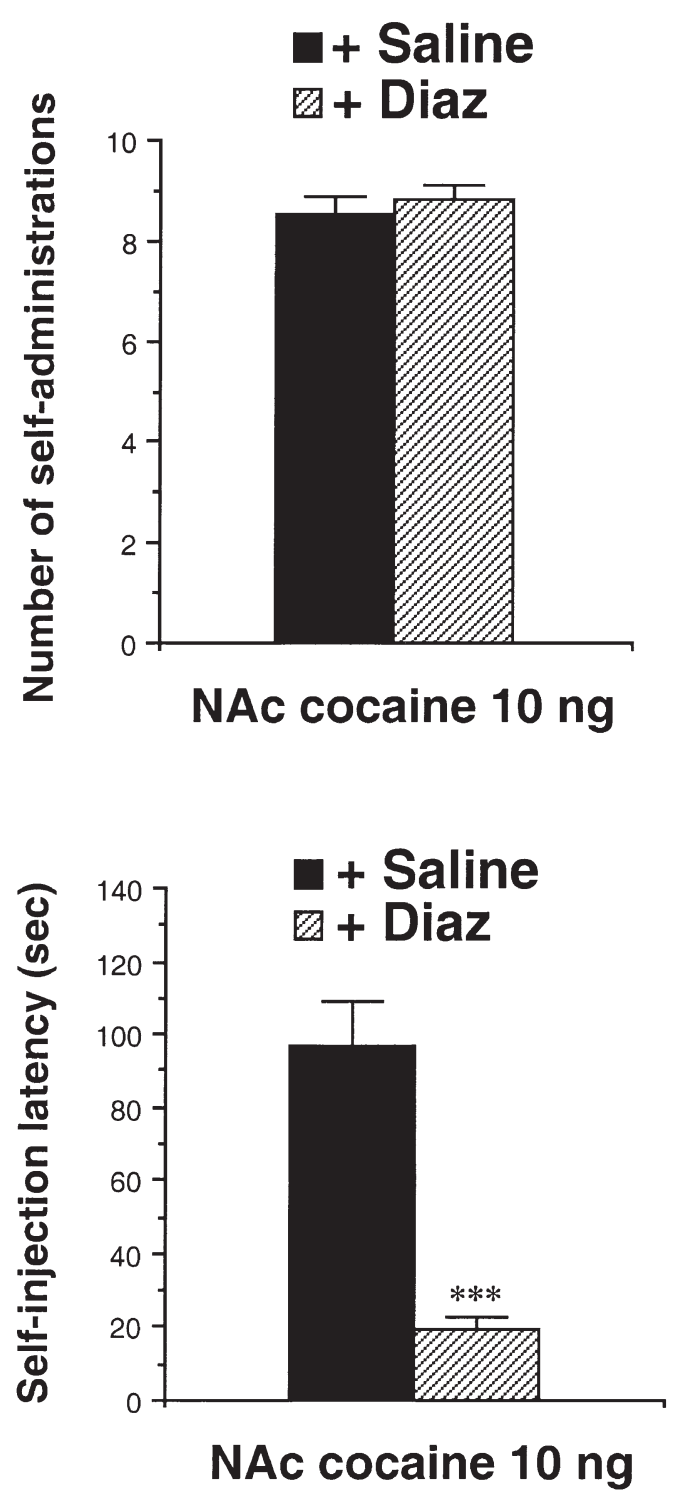

Figure 7. Effects of $\mathrm{NaCl}$ or diazepam $(1 \mathrm{mg} / \mathrm{kg} \mathrm{IP})$ on the number of self-administrations and the injection latency in the NAc group (cocaine $10 \mathrm{ng}$ ). ${ }^{* * *} p<.001$ Student's $t$-test comparing the mean of diazepam versus $\mathrm{NaCl}$ groups.

findings, all subjects were considered accurately implanted, and, thus, none were eliminated.

\section{DISCUSSION}

\section{Intravenous Cocaine Self-Administration in BALB/cByJ}

The first observation resulting from the present experiment is that BALB/cByJ mice exhibited intravenous cocaine self-administration behavior when using a low dose known to be ineffective in several other strains (Carney et al. 1991; Grahame et al. 1995; Deroche et al. 1997; Rocha et al. 1998). The use of a habituation session

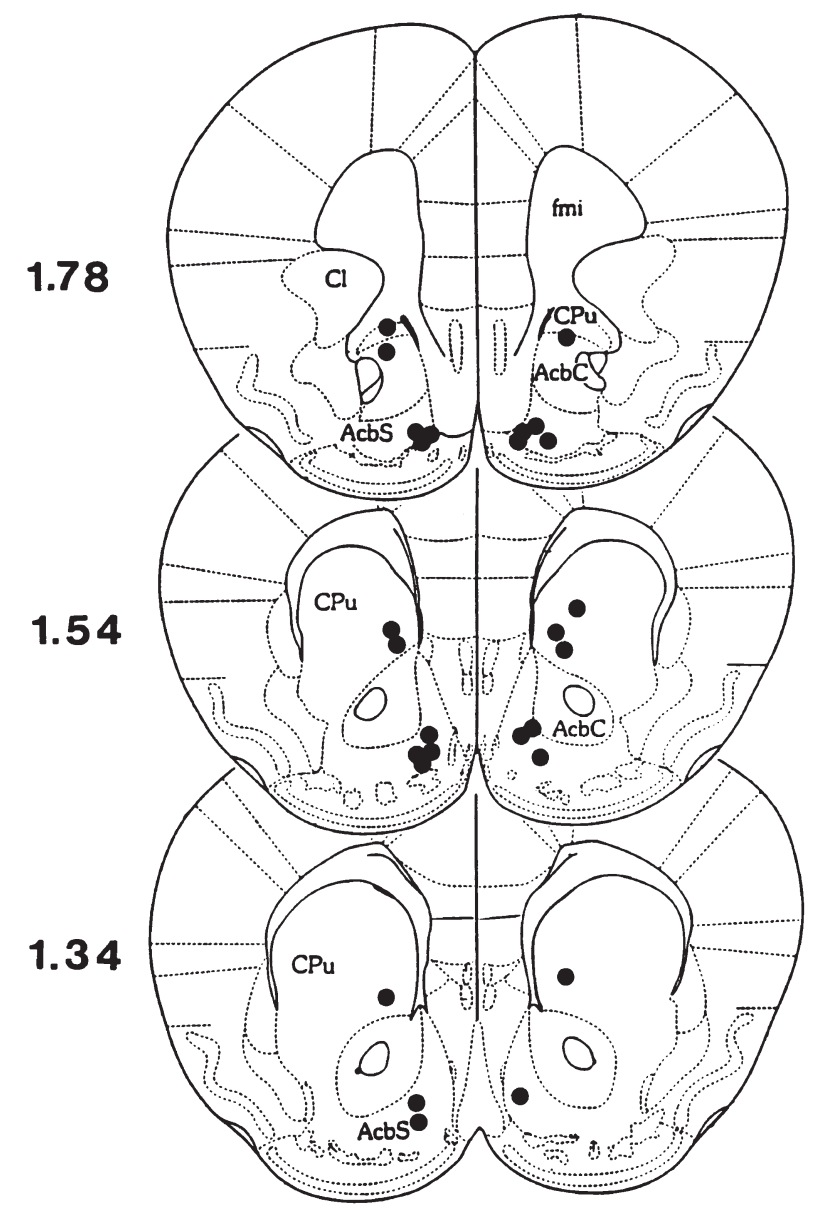

Figure 8. The locations of the injection sites in the NAc and $\mathrm{CPu}$ are plotted on frontal section diagrams. The values indicate the distance $(\mathrm{mm})$ of the section from bregma (based on Franklin and Paxinos's stereotaxic atlas, with permission of Academic Press) (AcbC, accumbens nucleus core; AcbS, accumbens nucleus shell; $\mathrm{Cl}$, claustrum; $\mathrm{CPu}$, caudate putamen; fmi, forceps minor corpus callosum).

allowing the mice to explore the apparatus freely before cocaine was made available may have favored the expression of this behavior. However, this initially positive reaction was quickly (5-6 days) followed by a progressive reduction of the number of intravenous cocaine injections. Because we and others have shown that higher acquisition doses are associated with lower rates of self-administration in BALB/cByJ mice (Deroche et al. 1997; Yu et al. 1997), it is unlikely that the observed reduction in intravenous self-administration was attributable to the use of a subthreshold dose of cocaine. In fact, higher doses have been shown to produce even greater disruption, with the dose of $1 \mathrm{mg} / \mathrm{kg} / \mathrm{inj}$ leading to a sudden cessation of responding (Deroche et al. 1997). These observations also suggest that pharmacological tolerance is not responsible for the decrease in responding. Tolerance is more likely to be expressed as an increase in responding in self-administration experi- 

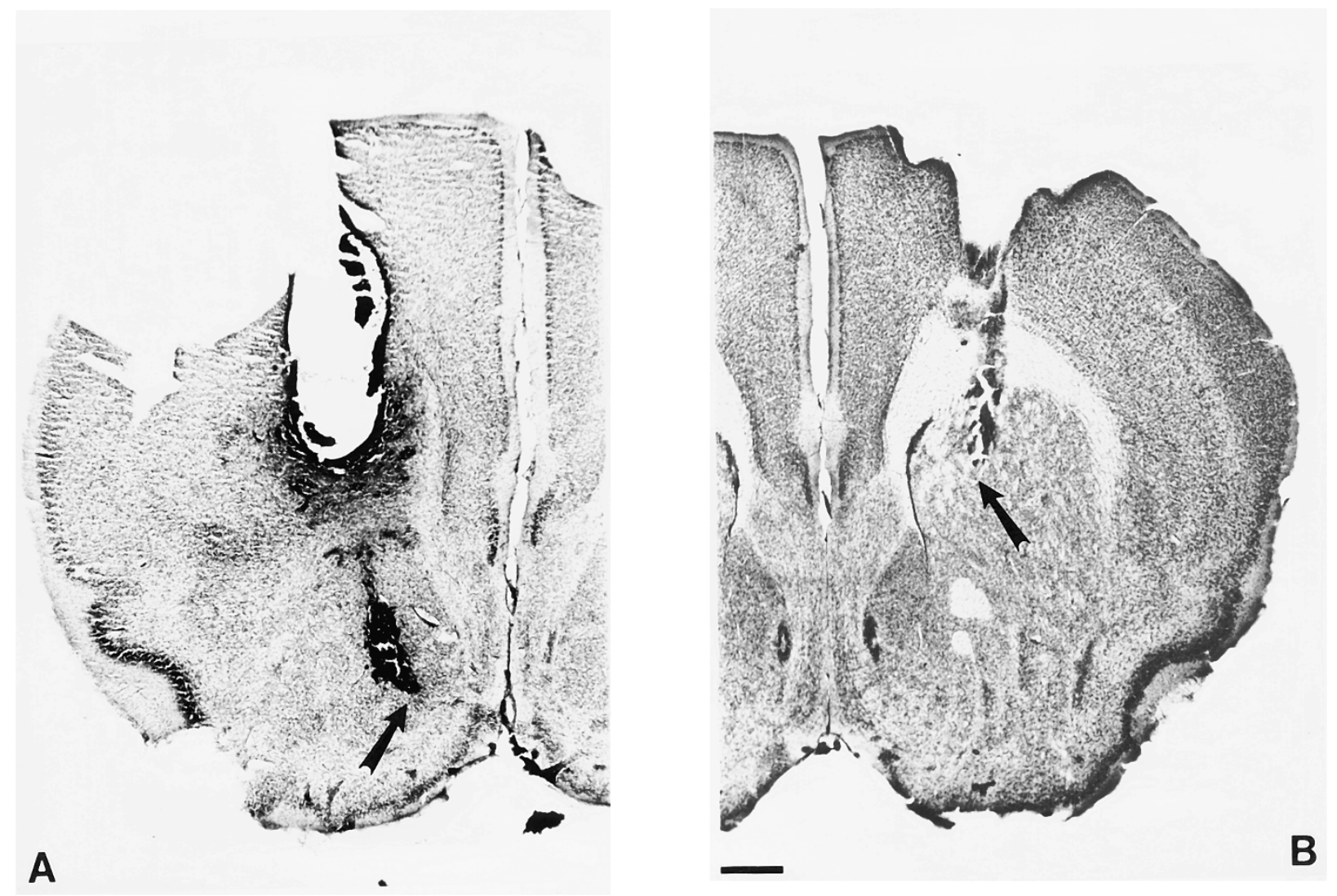

Figure 9. Photomicrograph of a thionin-stained frontal brain section (60 microns) through the guide-cannula and the injection cannula tracks into the NAc (a), $\mathrm{CPu}$ (b). Arrows indicate the tip of the injection cannula (injection sites). Scale bar, $0.50 \mathrm{~mm}$.

ments using a fixed ratio schedules of reinforcement (Yokel 1987; Emmett-Oglesby et al. 1993).

Interestingly, BALB/cByJ mice are more sensitive than other strains to the stimulant effects of low doses of cocaine, but dose-related increases in activity are not observed (Schuster et al. 1977; Ruth et al. 1988; Reith and Selmeci 1992; Elmer et al. 1996; Deroche et al. 1997). This strain also shows enhanced response to the cellular or behavioral effects of a variety of stressors (see introductory remarks). Therefore, BALB/cByJ mice may be highly sensitive to both the rewarding and aversive effects of cocaine, and the extinction of self-administration could result from a sensitization of the anxiogenic properties of cocaine. In this view, diazepam would act by relieving anxiety rather than by enhancing euphoria directly. Although the increase in drug intake with diazepam may reflect an attempt to overcome a decrease in cocaine reinforcement produced by diazepam, this is unlikely, because the reduction in responding was evident before the diazepam treatments were begun. Thus, to argue that during diazepam treatment mice are overcoming a further decrease, it must be postulated that both a decrease (before treatment) and an increase (during treatment) in responding are related to a reduction of reinforcement.
Nevertheless, an alternative interpretation can be suggested. Context-dependent sensitization to the stimulating and reinforcing effects of cocaine has been described in rats and mice (Elmer et al. 1996; Duvauchelle et al. 2000) and chlordiazepoxide and alprazolam have been reported to decrease cocaine IVSA (Goeders et al. $1989,1993)$. On the basis of the group results from intravenous self-administration experiments alone, one cannot exclude the hypothesis that sensitization to the rewarding effect of cocaine is responsible for the decrease in self-administration and that diazepam would increase self-administration rates by decreasing the rewarding effects of cocaine.

Several lines of evidence argue against this hypothesis. If diazepam decreases the reinforcing effects of cocaine, mice that showed evidence of sensitization to the rewarding effects would respond to diazepam, and mice that did not show evidence of sensitization would not respond to diazepam. Moreover, mice with higher exposure to cocaine (sensitized) should be more responsive to diazepam. We found no relationship between cocaine intake in individual animals during training and diazepam effects on self-administration, and mice with a lower cocaine intake throughout the acquisition phase displayed a strong increase in cocaine 
self-administration following diazepam treatment. Also, the observation of a very irregular pattern of responding over days further suggests the presence of conflict-like behaviors rather than a gradual sensitization. It is clear from the individual data that diazepam suppressed the irregular pattern of responding, rather than reversing a gradually decreasing self-administration. Therefore, context and time-dependent sensitization to reinforcing properties of cocaine is not likely to explain the diazepam effects on cocaine self-administration in BALB/cByJ mice.

Diazepam may also have enhanced cocaine's positive reinforcing effects. However, results from the intracranial self-administration study clearly support the hypothesis of the attenuation of anxiety-like effects. In fact, the decline in intravenous cocaine self-administration was paralleled by an anxiety-like behavior expressed by mice self-injecting consistently cocaine into the NAc. Over successive acquisition sessions, these mice made an increasing number of shuttles between the reinforced arm and the start box, this behavior contributing to a significant lengthening of the latency to self-inject cocaine into the NAc. This was unexpected because, in this paradigm, choice of the reinforced arm has been consistently associated with a decrease in the latency to trigger drug injection (see David and Cazala 1994; David et al. 1998a). Although initial reaction to cocaine in humans is reported to be euphoric, strong anxiogenic properties in humans, monkeys, rats, and mice have been described, mediated at least in part via a CRF mechanism (Aronson and Craig 1986; Moldow and Fischman 1987; Rivier and Vale 1987; Anthony et al. 1989; Ettenberg and Geist 1991; Crowley et al. 1992; Yang et al. 1992; Sarnyai 1998). Of particular interest in this context is the observation that rats self-administering $\mathrm{co}^{-}$ caine intravenously in a runway exhibit a form of conflict behavior manifested by an increase in the number of "retreats" from the goal box to the start compartment. The "shuttling behavior" observed in the present study is likely to be the mouse analog of this "retreat behavior" described in rats. Consistent with this relationship, pretreatment with diazepam reduces both phenomena (Ettenberg and Geist 1991, 1993). Interestingly, restriction of cocaine injections to the NAc elicited stable self-administration but did not eliminate conflict-like behaviors, suggesting that this region may also mediate anxiogenic or negative affective states.

\section{Anatomical and Pharmacological Specificity of Intra-NAc Cocaine Self-Administration}

Cocaine injections into the NAc maintained self-administration. One concern raised by intracranial injections involves the anatomical specificity of the behavioral effects of the substance injected. Because of the pressure gradient created by repetitive introduction of the can- nula, diffusion occurs mainly in a dorsal direction (Wise and Hoffman 1992). However, when injection cannula were located $0.8 \mathrm{~mm}$ above the NAc injection sites, into the anterodorsal part of the $\mathrm{CPu}$ or NAc core, mice did not discriminate between the reinforced arm and the neutral arm of the $Y$ maze. This suggests that a neuronal substrate within the NAc or a radius of approximately $0.8 \mathrm{~mm}$ from the injection site plays a predominant role in the ICSA of cocaine. These results support observations from previous intracranial selfadministration and place conditioning studies that the $\mathrm{CPu}$ is not part of the primary brain reward system and extend these conclusions to mice (for review McBride et al. 1999). However, an interesting phenomenon was observed in the $\mathrm{CPu}$ group. Although discrimination performance remained at chance level, over the successive acquisition sessions, $\mathrm{CPu}$ animals showed a decrease in the latency to enter both the reinforced and the neutral arm. These data suggest that injection of cocaine into the $\mathrm{CPu}$ exerts a general behavioral activation of mice. However, because animals were slower to complete the last trial versus the first trial of each session, this effect may not correspond to an acute cocaine-induced stimulant effect. Furthermore, it is of interest to note that $\mathrm{NAc}$ and $\mathrm{CPu}$ mice injected with the high dose of cocaine exhibited self-injection latencies that were not significantly different. Therefore, partial diffusion from the $\mathrm{CPu}$ to the NAc may account for this phenomenon, thus explaining the similarity of latencies in both groups. However, discrimination performances remained at chance level in $\mathrm{CPu}$ mice, demonstrating that diffusion did not induce sufficient interoceptive cues to affect spatial discrimination performance of the mice. Thus, $\mathrm{CPu}$ animals made random choices during the acquisition phase but showed a reduction of injection latencies over days; whereas, NAc subjects exhibited ICSA behavior associated with progressive increases of the response latencies. This double dissociation further confirms the anatomical specificity of the effects elicited by central injection in our experimental conditions.

The disruptive effect of sulpiride on ICSA of cocaine is consistent with previous data. Co-infusion of equimolar concentrations of sulpiride and cocaine attenuates cocaine self-administration into the prefrontal cortex of the rat, which seems to activate NAc dopaminergic elements (Goeders and Smith 1983, 1993). This effect also is consistent with a role of NAc dopamine and dopamine D2 receptors in cocaine IVSA (Roberts and Vickers 1984; Woolverton 1986; Robledo et al. 1992; Wise et al. 1995) and local electrophysiological effects of cocaine (White et al. 1993; Uzwiak et al. 1997). Although it is known that cocaine decreases dopamine (Komiskey et al. 1977; Hadfield et al. 1980), noradrenaline (Dubocovich et al. 1979; Hadfield and Nugent 1980), and serotonin uptake (Taylor and Ho 1978), and increases acetylcholine release (Day et al. 1997), our results point to a role for a dopa- 
minergic D2 mechanism in the rewarding effects of cocaine administered into the NAc. Because replacement of sulpiride by $\mathrm{NaCl}$ led to the immediate recovery of intra-NAc cocaine self-administration, it is unlikely that chance level responding would have occurred independently of the D2 antagonist treatment. Also, the observation that latencies to injection are not significantly increased during the first days of sulpiride pretreatment, although drug choice is reduced, argue for motivational rather than motor effects.

Two major subregions have been described within the NAc of the rat: a medioventral part ("shell") and a laterodorsal part called ("core") (Alheid and Heimer 1988; Heimer et al. 1997). The shell receives dopaminergic projections from the ventral tegmental area and is linked to the bed nucleus of the stria terminalis and the mediocentral amygdala, forming an interface with the "extended amygdala" hypothesized to be involved in drug reward (Koob et al. 1993). The core receives dopaminergic projections primarily from the substantia nigra and is involved more specifically in the regulation of motor activity (Kalivas et al. 1993). In rats, behavioral studies suggest that the shell is involved in rewarding properties of cocaine. Ibotenic acid lesions of an output of the NAc shell, the sublenticular ventral pallidum, decrease responding for intravenous cocaine (Hubner and Koob 1990; Robledo and Koob 1993). Moreover, amphetamine, cocaine, and nomifensine as well as D1 and D2 dopaminergic agonists are self-injected into this subregion (Hoebel et al. 1983; Carlezon et al. 1995; Ikemoto et al. 1997; McKinzie et al. 1999). A core placement could explain the negative results reported by an early study looking at cocaine intra-NAc self-administration in rats (Goeders et al. 1983). A core/shell distinction can be anatomically defined in mice (Franklin and Paxinos 1997). However, little is known about its functional relevance. Although the core and shell were not directly compared in the present study: (1) all NAc subjects exhibiting ICSA behavior were implanted in the shell; and (2) animals of the $\mathrm{CPu}$ group implanted at the level of the core/ $\mathrm{CPu}$ borderline did not exhibit any positive reaction to the effects of cocaine. Thus, our results provide preliminary evidence for the functional relevance of the core/shell distinction in mice.

\section{Clinical Relevance: A Mechanism Underlying Vulnerability to Drug Abuse}

Rodent and human emotional reactivity are psychological traits with a well-characterized genetic basis (Flint et al. 1995; Eley and Plomin 1997). In each species, this trait is linked with susceptibility to anxiety (Belzung and Berton 1997; Eley and Plomin 1997). Therefore, the finding that an anxiolytic pretreatment helped to maintain cocaine self-administration in an emotional strain of mice has clinical implications and calls attention to the increased addictive potential of mixed drug use. Indeed, caution has been advised for the use of diazepam in treating cocaine-induced anxiety, because of the possibility for relapse or secondary dependence to diazepam (Wesson and Smith 1985). Concurrent use of cocaine and diazepam or alcohol is a frequent form of stimulant abuse, suggesting that some cocaine users may try to control adverse consequences of drug use. The hypothesis that diazepam may have ameliorated the negative effects of cocaine in BALB/c mice is also relevant to the observation that anxious individuals are less likely to seek stimulants (Chutuape and DeWit 1995).

Finally, the present findings provide insight regarding the predictive value of vulnerability factors. First, it is suggested that subjects with very high novelty- or stress-associated emotional reactivity may be unlikely to develop stimulant-seeking behavior, because of a necessity to control secondary drug-induced anxiogenic effects. Second, sensitivity to the cellular or behavioral effects of stress mediators may have a protective action on the same behavior. This hypothesis is not inconsistent with the rat literature showing stress-induced stimulant self-administration (see Kreek 1996; Piazza and Le

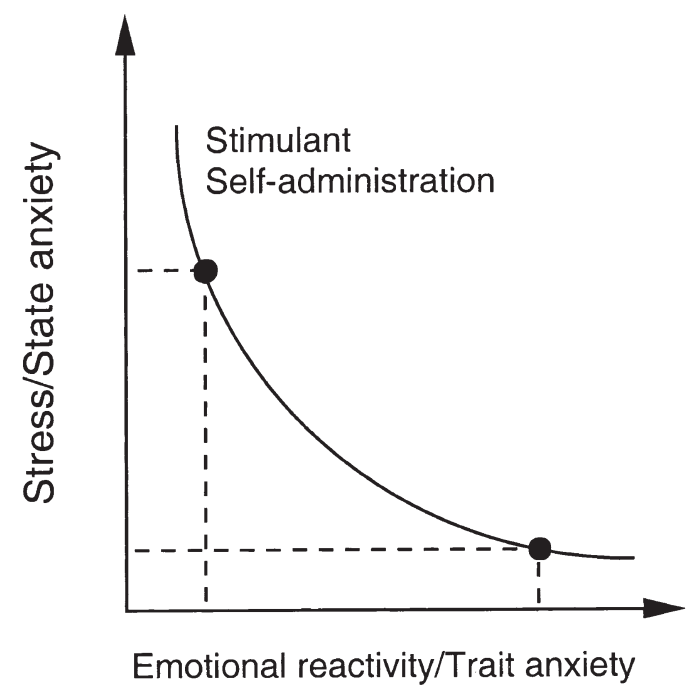

Figure 10. A hypothetical model of the regulatory role of emotional reactivity on drug-taking behavior. The ordinate and abscissa represent continuums increasing in the direction of the arrowheads. It is suggested that, to achieve the same level of self-administration or rewarding effects, low levels of stimulation are needed in emotional individuals (right circle); whereas, in high responders to novelty, an increased level of stimulation is required (left circle). Accordingly, the model provides an explanation for the observation that nonemotional strains of mice and rats self-administer higher doses of cocaine; whereas, lower acquisition doses maintain self-administration when associated with acute stressors. For further details see Discussion section. 
Moal 1996), but rather suggests that stressful stimuli may have opposite effects on drug self-administration depending on the basal activity of stress/anxiety systems. Furthermore, it may explain why, in rats with normally low levels of trait anxiety, stressful stimuli such as electrical foot shocks or CRF injections increase stimulant self-administration; whereas, anxiolytics (benzodiazepines) have been reported to decrease cocaine IVSA (Goeders et al. 1989, 1993). Specifically, individuals with low trait anxiety may need more stimulation to achieve the same rewarding experience than individuals with high trait anxiety (Figure 10). Accordingly, evidence from several previous studies show that nonemotional inbred strains such as C57BL/ 6 readily self-administer high doses of cocaine (Carney et al. 1991; Grahame et al. 1995; Rocha et al. 1998), and we have shown qualitative and quantitative differences in self-administration between BALB/cByJ and C57BL/6 x SJL hybrid mice (Deroche et al. 1997).

Thus, the interaction between specific psychological traits (such as emotional reactivity) and the neuropharmacological profile of a given drug (such as cocaine) may be a primary factor contributing to, or preventing, the development of drug use. By showing how trait anxiety (BALB/cByJ) as a genetic factor, and cocaineinduced state anxiety as an environmental factor, may regulate the rate of cocaine-maintained responding, our results provide a model predicting the addictive potential of specific genetic-environment interactions. The adaptation of tasks relevant to drug-seeking behaviors for testing mice permits the examination of murine inbred strains that express various psychological traits related to human personality traits, as well as physiological traits and gene-targeted manipulations. Therefore, mouse self-administration models are a potentially valuable approach to study such vulnerability factors for drug abuse.

In conclusion, $\mathrm{BALB} / \mathrm{cByJ}$ mice are sensitive to the rewarding effects of cocaine, which seem to be mediated, at least, in part by dopamine D2 receptors within the ventromedial part of the NAc. They are also sensitive to the aversive effects associated with cocaine use, eventually leading to the interruption of intravenous self-administration. Although the NAc supports cocaine-seeking behavior, intra-NAc self-administration resulted in increased latencies associated with the emergence of an approach-avoidance behavior, suggesting that ventral NAc could be involved in both the rewarding and aversive effects of cocaine. An anxiolytic pretreatment (diazepam 0.5 and $1 \mathrm{mg} / \mathrm{kg}$ ) improved the performance in both self-administration paradigms, presumably by alleviating the aversive effects associated with the chronic use of the drug. These results highlight the critical role of a specific phenotypic interaction between genetic (trait anxiety) and environmental (cocaine) factors in vulnerability to drug abuse.

\section{ACKNOWLEDGMENTS}

We thank Drs. A. Contarino, R. Picetti, A. Roberts, and M. Taffe for their helpful comments on a earlier version of the manuscript; M. Arends for skillful editorial assistance, and L. Decorte, T. Lafon, B. Lintz, D. Panzeri, and I. Polis for excellent technical assistance. This investigation was supported by the CNRS (UMR 5807) and Grant DA 10191(LHG). This is publication 12605-NP from The Scripps Research Institute.

\section{REFERENCES}

Alheid GF, Heimer L (1988): New perspectives in basal forebrain organization of special relevance for neuropsychiatric disorders: The striatopallidal, amygdaloid, and corticopetal components of substantia innominata. Neurosci 27:1-39

Anthony JC, Tien AY, Petronis KR (1989): Epidemiologic evidence on cocaine use and panic attacks. Am J Epidemiol 129:543-549

Aronson TA, Craig TJ (1986): Cocaine precipitation of panic disorder. Am J Psychiat 143:643-645

Bardo MT (1998): Neuropharmacological mechanisms of drug reward: Beyond dopamine in the nucleus accumbens. Crit Rev Neurobiol 12:37-67

Bardo MT, Donohew RL, Harrington NG (1996): Psychobiology of novelty-seeking and drug seeking behavior. Behav Brain Res 77:23-43

Belzung C, Berton F (1997): Further pharmacological validation of the BALB/c neophobia in the free exploratory paradigm as an animal model of trait anxiety. Behav Pharmacol 8:541-548

Borde N, Jaffard R, Beracochea D (1998): Effects of chronic alcohol consumption or Diazepam administration on item recognition and temporal ordering in a spatial working memory task in mice. Eur J Neurosci 7:2380-2387

Borisenko SA, Meng QH, Rauhala P, Mannisto PT (1996): Neurochemical mediators of anxiety have inconsistent effects on hypothalamic self-stimulation in rats. Pharmacol Toxicol 78:354-360

Borsini F, Brambilla A, Cesana R, Donetti A (1993): The effect of DAU 6215, a novel 5HT-3 antagonist, in animal models of anxiety. Pharmacol Res 27:151-164

Caine SB, Negus SS, Mello NK (1999): Method for training operant responding and evaluating cocaine self-administration behavior in mutant mice. Psychopharmacology 147:22-24

Carlezon WA, Devine DP, Wise RA (1995): Habit-forming actions of nomifensine in nucleus accumbens. Psychopharmacology 122:194-197

Carney JM, Landrum RW, Cheng MS, Seale TW (1991): Establishment of chronic intravenous drug self-administration in the C57BL/6J mouse. Neuroreport 2:477-480

Cazala P (1976): Effects of $d$ - and l-amphetamine on dorsal and ventral hypothalamic self-stimulation in three inbred strains of mice. Pharmacol Biochem Behav 5:505-510

Chutuape MA, DeWit H (1995): Preferences for ethanol and 
diazepam in anxious individuals: An evaluation of the self-medication hypothesis. Psychopharmacology 121:91-103

Conti L, Costello DG, Martin LA, White MF, Abreu ME (1994): Mouse strain differences in the behavioral effects of corticotropin-releasing factor (CRF) and the CRF antagonist $\propto$-helical $\mathrm{CRF}_{9-41}$. Pharmacol Biochem Behav 48:497-503

Crabbe JC, Belknap JK, Buck KJ (1994): Genetic animal models of alcohol and drug abuse. Science 205:1715-1723

Crowley TJ, Mikulich SK, Williams EA, Zerbe GO, Ingersoll NC (1992): Cocaine, social behavior, and alcohol-solution drinking in monkeys. Drug Alcohol Depend 29:205-223

David V, Cazala P (1994): Differentiation of intracranial morphine self-administration behavior among five brain regions in mice. Pharmacol Biochem Behav 48:625-633

David V, Durkin TP, Cazala P (1998a): Rewarding effects elicited by microinjection of either AMPA or NMDA glutamatergic antagonists into the ventral tegmental area revealed by an intracranial self-administration paradigm in mice. Eur J Neurosci 10:1394-1402

David V, Polis I, Contarino A, Gold LH (1998b): Intravenous self-administration of heroin and a heroin/cocaine mixture (speedball) using nose-poke or lever-press operant responding in mice. Soc Neurosci Abstr 24:500

Davis WM, Smith SG (1987): Conditioned reinforcement as a measure of the reward properties of drugs. In Bozarth MA (ed), Methods of Assessing the Reinforcing Properties of Abused Drugs. New York, Springer-Verlag pp. 199-210

Day JC, Piazza PV, Le Moal M, Maccari S (1997): Cocaineinduced increase in cortical acetylcholine release: Interaction with the hypothalamo-pituitary-adrenal axis. Eur J Neurosci 9:1130-1136

Deneau G, Yanagita T, Seevers MH (1969): Self-administration of psychoactive substances by the monkey. Psychopharmacologia 16:30-48

Deroche V, Caine SB, Heyser, CJ, Polis I, Koob GF, Gold LH (1997): Differences in the liability to self-administer intravenous cocaine between C57BL/6 $\times$ SJL and BALB/cByJ mice. Pharmacol Biochem Behav 57:429_ 440

Dubocovich ML, Langer SZ, Pelayo F (1979): Cocaine and desipramine antagonize the clonidine-induced inhibition of $\left[{ }^{3} \mathrm{H}\right]$-noradrenaline release from the rat cerebral cortex. Br J Pharmacol 67:417-418

Duvauchelle CL, Ikegami A, Asami S, Robens J, Kressin K, Castaneda E (2000): Effects of cocaine context on NAcc dopamine and behavioral activity after repeated intravenous cocaine administration. Brain Res 862:49-58

Eley TC, Plomin R (1997): Genetic analyses of emotionality. Curr Opin Neurobiol 7:279-284

Elmer GI, Gorelick DA, Goldberg SR, Rothman RB (1996): Acute sensitivity vs. context-specific sensitization to cocaine as a function of genotype. Pharmacol Biochem Behav 53:623-628

Emmett-Oglesby MW, Peltier RL, Depoortere RY, Pickering CL, Hooper ML, Gong YH, Lane JD (1993): Tolerance to self-administration of cocaine in rats: Time course and dose-response determination using a multidose method. Drug Alcohol Depend 32:247-256

Ettenberg A, Geist TD (1991): Animal model for investigating the anxiogenic effects of self-administered cocaine. Psychopharmacology 103:455-461

Ettenberg A, Geist TD (1993): Qualitative and quantitative differences in the operant runway behavior of rats working for cocaine and heroin reinforcement. Pharmacol Biochem Behav 44:191-198

Fischman MW, Schuster CR (1982): Cocaine self-administration in humans. Federation Proc 41:241-246

Flint J, Corley R, DeFries JC, Fulker DW, Gray JA, Miller S, Collins AC (1995): A simple genetic basis for a complex psychological trait in laboratory mice. Science 269:1432-1435

Franklin KBJ, Paxinos G (1997): The Mouse Brain in Stereotaxic Coordinates. San Diego, Academic Press

Goeders NE, Smith JE (1983): Cortical dopaminergic involvement in cocaine reinforcement. Science 221:773-775

Goeders NE, Smith JE (1993): Intracranial self-administration into the medial prefrontal cortex increases dopamine turnover in the nucleus accumbens. J Pharmacol Exp Ther 265:592-265

Goeders NE, McNulty MA, Mirkis S, McAllister KH (1989): Chlordiazepoxide alters intravenous cocaine selfadministration in rats. Pharmacol Biochem Behav 33:859-866

Goeders NE, McNulty MA, Guerin GF (1993): Effects of alprazolam on intravenous cocaine self-administration in rats. Pharmacol Biochem Behav 44:471-474

Goldberg SR (1973): Comparable behavior maintained under fixed-ratio and second-order schedules of food presentation, cocaine injection or d-amphetamine injection in the squirrel monkey. J Pharmacol Exp Ther 186:18-30

Grahame NJ, Phillips TJ, Burkhart-Kasch S, Cunningham CL (1995): Intravenous cocaine self-administration in the C57BL/6J mouse. Pharmacol Biochem Behav 51:827-834

Hadfield MG, Mott DEW, Ismay JA (1980): Cocaine: Effect of in vivo administration on synaptosomal uptake of norepinephrine. Biochem Pharmacol 29:1861-1863

Hadfield MG, Nugent EA (1980): Cocaine: Comparative effect on dopamine uptake in extrapyramidal and limbic systems. Biochem Pharmacol 32:774-776

Harris T, Bielajew C (1991): Diazepam alters brain-stimulation reward thresholds in seizure-prone sites. Behav Brain Res 46:167-173

Heimer L, Alheid GF, de Olmos JS, Groenewegen HJ, Haber SN, Harlan RE, Zahm DS (1997): The accumbens: Beyond the core-shell dichotomy. J Neuropsychiat Clin Neurosci 9:354-381

Hervé D, Tassin JP, Barthelemy C, Blanc G, Lavielle S, Glowinski J (1979): Difference in the reactivity of the mesocortical dopaminergic neurons to stress in the BALB/c and C57 BL/ 6 mice. Life Sci 25:1659-1664

Heyser CJ, McDonald JS, Beauchamp V, Koob GF, Gold LH (1997): The effects of cocaine on operant responding for food in several strains of mice. Psychopharmacology 132:202-208 
Hoebel BG, Monaco AP, Hernandez L, Aulisi EF, Stanley BG, Lenard L (1983): Self-injection of amphetamine directly into the brain. Psychopharmacology 81:158-163

Hooks MS, Jones GH, Smith AD, Neill DB, Justice JB Jr (1991): Response to novelty predicts the locomotor and nucleus accumbens dopamine response to cocaine. Synapse 9:121-128

Hubner CB, Koob GF (1990): The ventral pallidum plays a role in mediating cocaine and heroin self-administration in the rat. Brain Res 508:20-29

Ikemoto S, Glazier BS, Murphy JM, McBride WJ (1997): Role of dopamine D1 and D2 receptors in the nucleus accumbens in mediating reward. J Neurosci 17:8580-8587

Kalivas PW, Churchill L, Klitenick MA (1993): The circuitry mediating the translation of motivational stimuli into adaptative motor responses. In Kalivas PW, Barnes CD (eds), Limbic Motor Circuits and Neuropsychiatry. Boca Raton, CRC Press, pp 237-287

Komiskey HL, Miller DD, LaPidus JB, Patil PN (1977): The isomers of cocaine and tropacocaine: Effect on ${ }^{3} \mathrm{H}$-cathecolamine uptake by rat brain synaptosomes. Life Sci 21:1117-1122

Koob GF, Robledo P, Markou A, Caine SB (1993): The mesocorticolimbic circuit in drug dependence and reward: A role for the extended amygdala? In Kalivas PW, Barnes CD (eds), Limbic Motor Circuits and Neuropsychiatry. Boca Raton, CRC Press, pp 214-263

Kreek MJ (1996): Cocaine, dopamine, and the endogenous opioid system. J Addict Dis 15:73-96

McBride W, Murphy JM, Ikemoto S. (1999): Localization of brain reinforcement mechanisms: Intracranial selfadministration and intracranial place-conditioning studies. Behav Brain Res 101:129-152

McKinzie DL, Rodd-Henricks ZA, Dagon CT, Murphy JM, McBride WJ (1999): Cocaine is self-administered into the shell region of the nucleus accumbens in Wistar rats. Ann NY Acad Sci 877:788-791

Meririnne E, Kankaanpaa A, Lillsunde P, Seppala T (1999): The effects of diazepam and zolpidem on cocaine- and amphetamine-induced place preference. Pharmacol Biochem Behav 62:159-164

Moldow RL, Fischman AJ (1987): Cocaine-induced secretion of ACTH, beta-endorphin, and corticosterone. Peptides 8:819-822

O'Brien CP, Ehrman RN, Terns JN (1986): Classical conditioning in human opioid dependence. In Goldberg SR, Stolerman IP (eds), Behavioral Analysis of Drug dependence. Orlando: Academic Press pp. 329-356

Piazza PV, Le Moal M (1996): Pathophysiological basis of vulnerability to drug abuse: Role of an interaction between stress, glucocorticoids, and dopaminergic neurons. Ann Rev Pharmacol Toxicol 36:359-378

Pickens R, Thompson T (1968): Cocaine-reinforced behavior in rats: Effects of reinforcement magnitude and fixedratio size. J Pharmacol Exp Ther 161:122-129

Reith ME, Selmeci G (1992): Cocaine binding sites in mouse striatum, dopamine autoreceptors, and cocaine-induced locomotion. Pharmacol Biochem Behav 41:227-330

Rivier C, Vale W (1987): Cocaine stimulates adrenocorticotropin (ACTH) secretion through a corticotropinreleasing factor (CRF)-mediated mechanism. Brain Res 422:403-406
Roberts AJ, Polis IY, Gold LH (1997): Intravenous selfadministration of heroin, cocaine, and the combination in Balb/c mice. Eur J Pharmacol 326:119-125

Roberts DCS, Vickers G (1984): Atypical neuroleptics increase self-administration: An evaluation of a behavioral screen for antipsychotic activity. Psychopharmacology 82:135-139

Robledo P, Koob GF (1993): Two discrete nucleus accumbens projection areas differentially mediate cocaine selfadministration in the rat. Behav Brain Res 55:159-166

Robledo P, Maldonado-Lopez R, Koob GF (1992): Role of dopamine receptors in the nucleus accumbens in the rewarding properties of cocaine. Ann NY Acad Sci 654:509-512

Rocha BA, Odom LA, Barron BA, Ator R, Wild SA, Forster MJ (1998): Differential responsiveness to cocaine in C57BL/6J and DBA/2J mice. Psychopharmacology 138:82-88

Rocha BA (1999): Methodology for analyzing the parallel between cocaine psychomotor stimulant and reinforcing effects in mice. Psychopharmacology 147:27-29

Ruth JA, Ullman EA, Collins AC (1988): An analysis of cocaine effects on locomotor activities and heart rate in four inbred mouse strains. Pharmacol Biochem Behav 29:157-162

Sarnyai Z (1998): Neurobiology of stress and cocaine addiction. Studies on corticotropin-releasing factor in rats, monkeys, and humans. Ann NY Acad Sci 851:371-387

Schuster L, Yu G, Bates A (1977): Sensitization to cocaine stimulation in mice. Psychopharmacologia 52:185-190

Shanks N, Griffiths J, Zalcman S, Zacharko RM, Anisman H (1990): Mouse strain differences in plasma corticosterone following uncontrollable foot shock. Pharmacol Biochem Behav 36:515-519

Siegel RK (1984): Changing patterns of cocaine use: Longitudinal observations, consequences, and treatment. In Grabowski J (ed), Cocaine: Pharmacology, Effects, and Treatment Abuse. NIDA Research Monograph 50:92-110

Spyraki C, Fibiger HC (1988): A role for the mesolimbic dopamine system in the reinforcing properties of diazepam. Psychopharmacology 94:133-137

Tassin JP, Herve D, Blanc G, Glowinski J (1980): Differential effects of a 2-minute open-field session on dopamine utilization in the frontal cortices of BALB/c and C57BL/ 6 mice. Neurosci Lett 17:67-71

Taylor D, Ho BT (1978): Comparison of inhibition of monoamine uptake by cocaine, methylphenidate, and amphetamine. Res Commun Chem Pathol Pharmacol 21:67-75

Uzwiak AJ, Guyette FX, West MO, Peoples LL (1997): Neurons in accumbens subterritories of the rat: Phasic firing time-locked within seconds of intravenous cocaine selfinfusion. Brain Res 767:363-369

Wesson DR, Smith DE (1985): Cocaine: Treatment perspectives. NIDA Res Monogr 61:193-203

White FJ, Hu XT, Henry D (1993): Electrophysiological effects of cocaine in the rat nucleus accumbens: Microiontophoretic studies. J Pharmacol Exp Ther 266:10751084

White FJ, Wang RY (1983): Differential effects of classical 
and atypical antipsychotic drugs on A9 and A10 dopamine neurons. Life Sci 34:1161-1170

Winer BJ (1971): Statistical Principles in Experimental Design. New York, McGraw Hill

Wise RA, Hoffman DC (1992): Localization of drug reward mechanisms by intracranial injections. Synapse 10:247-263

Wise RA, Newton P, Leeb K, Burnette B, Pocock D, Justice JB Jr (1995): Fluctuations in nucleus accumbens dopamine concentration during intravenous cocaine self-administration in rats. Psychopharmacology 120:10-20

Woods JH, Schuster CR (1968): Reinforcement properties of morphine, cocaine, and SPA as a function of unit dose. Int J Addict 3:231-237

Woolverton WL (1986): Effects of a D1 and D2 dopamine antagonist on the self-administration of cocaine and piribedil by rhesus monkeys. Pharmacol Biochem Behav 24:531-535

Yang XM, Gorman AL, Dunn AJ, Goeders NE (1992): Anxiogenic effects of acute and chronic cocaine administration: Neurochemical and behavioral studies. Pharmacol Biochem Behav 41:643-650

Yokel RA (1987): Intravenous self-administration: Response rate, the effects of pharmacological challenges, and drug preference. In Bozarth MA (ed), Methods of Assessing the Reinforcing Properties of Abused Drugs. New York, Springer, pp 117-141

Yu YL, Spencer JJ, Self, DW (1997): Genetic differences in cocaine self-administration between C57BL/6 and BALB/c mice. Soc Neurosci Abstr 23:1099 